University of Nebraska - Lincoln

DigitalCommons@University of Nebraska - Lincoln

$11-2009$

\title{
Provenance signatures of the Antarctic lce Sheets in the Ross Embayment during the Late Miocene to Early Pliocene: The ANDRILL AND-1B core record
}

\author{
Franco M. Talarico \\ Università di Siena, talarico@unisi.it \\ Sonia Sandroni \\ Università di Siena, sandroni@unisi.it
}

Follow this and additional works at: https://digitalcommons.unl.edu/andrillrespub

Part of the Environmental Indicators and Impact Assessment Commons

Talarico, Franco M. and Sandroni, Sonia, "Provenance signatures of the Antarctic Ice Sheets in the Ross Embayment during the Late Miocene to Early Pliocene: The ANDRILL AND-1B core record" (2009). ANDRILL Research and Publications. 49.

https://digitalcommons.unl.edu/andrillrespub/49

This Article is brought to you for free and open access by the Antarctic Drilling Program at DigitalCommons@University of Nebraska - Lincoln. It has been accepted for inclusion in ANDRILL Research and Publications by an authorized administrator of DigitalCommons@University of Nebraska - Lincoln. 


\title{
Provenance signatures of the Antarctic Ice Sheets in the Ross Embayment during the Late Miocene to Early Pliocene: The ANDRILL AND-1B core record
}

\author{
F. M. Talarico \\ Dipartimento di Scienze della Terra, Università di Siena, Via Laterina 8, Siena, Italy \\ (Corresponding author; tel 39 577233812, fax 39 577233938, email talarico@unisi.it )

\section{S. Sandroni} \\ Museo Nazionale dell'Antartide, Università di Siena, Via Laterina 8, Siena, Italy
}

\begin{abstract}
Significant down-core modal and compositional variations are described for granule- to cobble-sized clasts in the Early Pliocene to Middle/Late Miocene sedimentary cycles of the AND-1B drill core at the NW edge of the Ross Ice Shelf (McMurdo Sound).

Long-term shifts in compositional patterns outline an evolving provenance which is interpreted as reflecting the combined effects and complex interactions among variations in ice volume, ice flow patterns and paleogeographic changes linked to the local tectonic and volcanic activity. High-frequency variations and the petrological features of the basement clast fraction provide direct information about the potential source regions during both glacial maxima and minima. Provenance of the more distal material is identified in the region between Ross Island and the Skelton-Mulock glacier area (South Victoria Land) (Plio-Late Miocene section) and in the Darwin Glacier catchment (Miocene section). The provenance shifts can be discussed for their implications on ice dynamic models for the glacial evolution recorded in the western Ross Embayment. Reconstructed ice flow directions are consistent with the glaciological models for the Last Glacial Maximum, and the provenance data corroborate the contributions of both the East and West Antarctic Ice Sheets in influencing the modifications of the ice flow pattern of grounded ice in the western Ross Embayment in Miocene to Pleistocene time.
\end{abstract}

Keywords: clasts, provenance, East Antarctic Ice Sheet, West Antarctic Ice Sheet, Pliocene, Miocene

\section{Introduction}

The Late Cenozoic glacial evolution in the Ross Embayment region has been influenced by three primary elements of the Antarctic cryosphere, the East Antarctic Ice Sheet (EAIS) the West Antarctic Ice Sheet (WAIS) and the Ross Ice Shelf (Figure 1) The two ice sheets are separated by the Transantarctic Mountains (TAM) and interact today, primarily where outlet glaciers from East Antarctica impinge on ice fed by ice streams that drain the WAIS (Figure 1). The mainly marine-based WAIS contributes at least $2 / 3$ of the present-day Ross Ice Shelf and it is considered much more unstable than the thicker EAIS (Hughes, 1973, 1977; Oppenheimer, 1998). Nevertheless, a detailed reconstruction of the oscillations of the two ice sheets is considered critical to any comprehensive models dealing with the behavior of the Antarctic Ice Sheets during climatic changes (e.g., Bart and Anderson, 2000). Glaciological reconstructions of grounded ice expansion within the Ross Embayment during the Last Glacial Maximum (LGM) (Denton and Hughes, 2000, 2002) indicate that the WAIS and EAIS interacted in the past similarly to modern times, but with an approximately equal contribution of East and West Antarctic sourced ice feeding into grounded ice in the Ross Sea area. Previous petrographic studies from the Ross Sea are also suggestive of a relatively equal contribution from each source during the LGM (e.g., Licht et al., 2005).
The ANDRILL McMurdo Ice Shelf (MIS) project (Naish et al., 2007) provides a unique access to a sedimentary record spanning the last $13 \mathrm{Ma}$ and potentially including important climatic events (e.g., the Pliocene climatic optimum and cooling) (Crowley, 1996; Raymo et al., 1996; Zachos et al., 2001; Lisiecki and Raymo, 2005).

The project recovered a 1,285 $\mathrm{m}$ drill core (AND-1B) from beneath the present-day McMurdo Ice Shelf (Figure 1), an extension of the Ross Ice Shelf at the SW margin of the Ross Sea. Due to its longer record and its location with respect to previous drillholes in the McMurdo Sound, the AND-1B record can play a key role in contributing new constraints on the dynamics of the Antarctic Ice Sheet system in the Ross Embayment during the Late Cenozoic, and more specifically to reconstruct the interaction between EAIS outlet glaciers and WAIS in pre-LGM time (Naish et al., 2007, 2009).

In this paper, we provide quantitative results based on logging of the gravel fraction (granule- to cobble-grain size classes) and on the petrographic characterization of intrusive and metamorphic clasts occurring in the lowermost section (from 400 mbsf to the hole bottom) of the AND-1B core, which span in time from Lower Pliocene (ca. 3.5 Ma) to Middle Miocene (ca. $13 \mathrm{Ma}$ ) (Wilson et al., $2007 \mathrm{a}, 2007 \mathrm{~b}$ ). The presented provenance data are integrated with the description of AND-1B core clasts for the uppermost $400 \mathrm{~m}$ of core in the Plio-Pleistocene record, which have been reported in a 


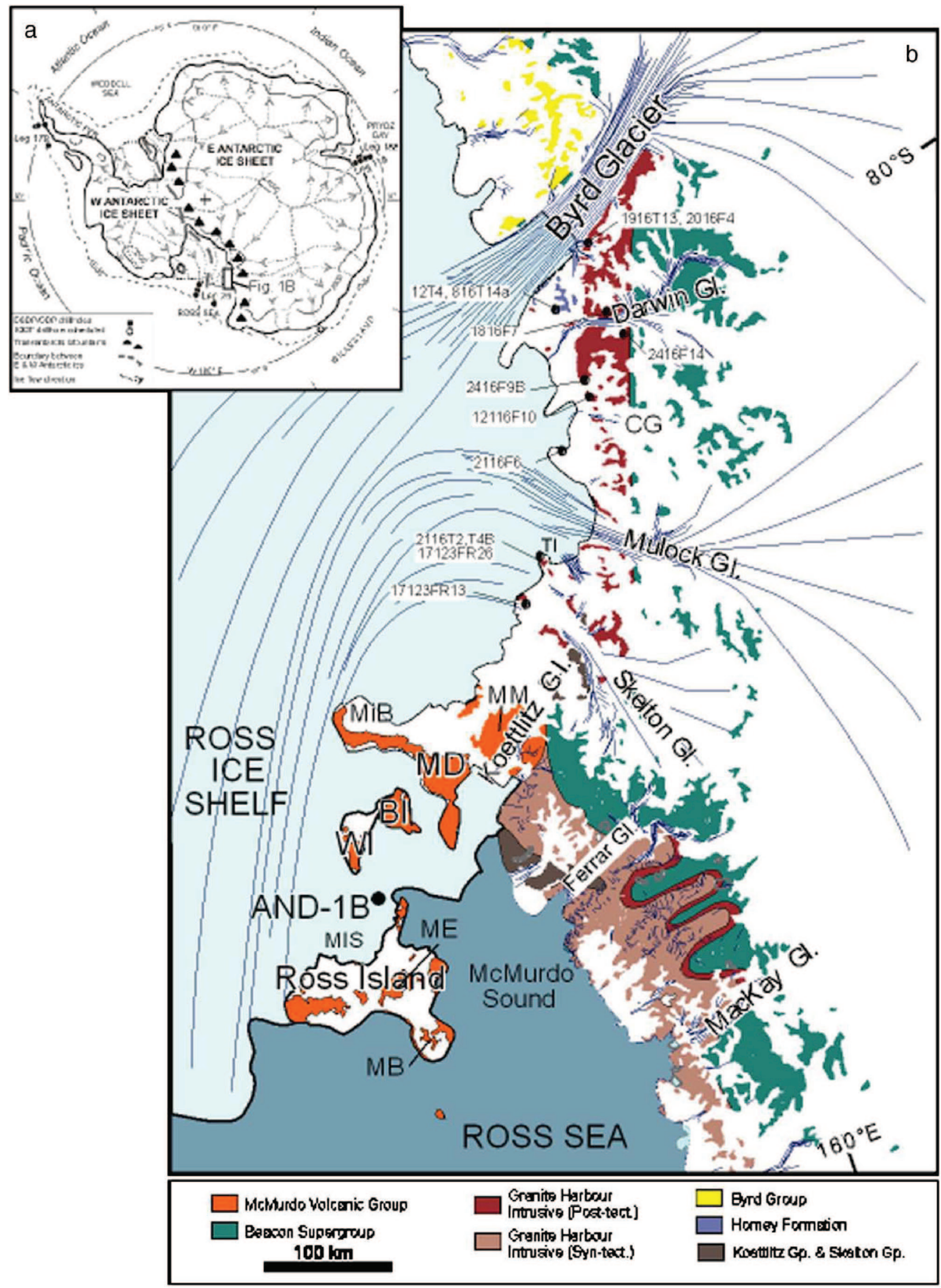


companion paper (Talarico et al., submitted for publication). The data set is used 1) to identify the dominant source areas for glacial debris, 2) to document compositional and textural variations with respect to sedimentary facies and glacial/interglacial sequence boundaries, and 3) to outline both long-term and short-term compositional patterns.

The results help to constrain significant steps in Antarctic Ice Sheet evolution through the Plio-Miocene, and address key questions regarding 1) the contribution of WAIS and EAIS to the sedimentary record at the SW end of the Ross Embayment in the Pliocene to Middle Miocene time, and 2) the assessment of the implications of AND-1B provenance constraints for glaciological models in comparison with LGM scenarios (e.g., Denton and Hughes, 2000, 2002; Denton and Marchant, 2000; Licht et al., 2005), as well as numerical ice sheets models (MacAyeal et al., 1996; Hulbe and MacAyeal, 1999; Ritz et al., 2001; Huybrechts, 2002).

\section{Geological setting}

AND-1B was drilled in the bathymetric and depocentral axis of a ca. $900 \mathrm{~m}$ deep basin that surrounds most of Ross Island, at the southern tip of the Terror Rift, a 70-km-wide structure that contains ca. $3.5 \mathrm{~km}$ of sediments, accumulated along its central axis since its inception during the Middle Miocene (Henrys et al., 2007). The Terror Rift lies near the western margin of the larger Victoria Land Basin (Figure 1), which is part of the West Antarctic Rift System (Cooper and Davey, 1985) and it is considered one of the sites of former ice streams that drained the WAIS- and EAISsourced outlet glaciers during the LGM (Hughes, 1977; Denton and Hughes, 2000; Mosola and Anderson, 2006).

The area surrounding the AND-1B drill site includes extensive outcrops of the Cenozoic alkalic Erebus Volcanic Province (Kyle, 1990) (Ross Island, White Island, Black Island, Minna Bluff and the Mount Discovery-Mount Morning peninsula) (Figure 1). The area lies immediately east of a major offset in the TAM rift flank inferred to mark a major transverse fault zone (Cooper et al., 1991). More recently, Wilson (1999) has linked linear elements from the distribution of Erebus Volcanic Province rocks with the flank segmentation and referred to the combined area beneath southern McMurdo Sound and the adjacent segmented TAM rift as the "Discovery Accommodation Zone".

Volcanic activity occurred during two main phases, an initial phase (19 to ca. $10 \mathrm{Ma}$ ) (e.g., Mount Morning (14.6 to $18.7 \mathrm{Ma}$ ), characterized by trachytic rocks, and a more voluminous second phase (last $10 \mathrm{Ma}$ ) that is dominated by basanitic to phonolitic sequences (Kyle, 1990). The emergence of these major volcanic centers during deposition of the AND-1B succession has potentially altered the past glacial flow-line pathways. The most notable volcanic emergences during the deposition of AND-1B sediments in the Lower Pliocene-Middle Miocene time window include: White Island (mainly $>0.2 \mathrm{Ma}$, but with volcanic deposits as old as 7.65 Ma, Cooper et al., 2007), Black Island (> 11.2 Ma at its northwest part, 3.9 to $3.4 \mathrm{Ma}$ ), Minna Bluff (11 to 7.26 Ma), Mount Discovery (5.44 to $1.78 \mathrm{Ma}$ ), and Mount Bird (ca. 4.6 Ma) (Armstrong, 1978; Kyle and Muncy, 1983; Wright-Grassham, 1987; Kyle, 1990; Wright and Kyle, 1990a, 1990b).

The volcanic centers are flanked to the west by the South Victoria Land (SVL) sector of the TAM which includes a crystalline basement composed of Late Precambrian to Cambrian metasedimentary clastics and carbonates (Ross Supergroup) and Early Paleozoic granitoids (Granite Harbor Intrusive Complex). The basement is overlain by a Devonian to Triassic sedimentary cover (Beacon Supergroup) which consists of a lower quartzose unit (Taylor Group) and an upper carbonaceous unit rich in feld- spathic sandstones (Victoria Group; Harrington, 1965). In Jurassic time, both basement complex and Beacon Supergroup were intruded by dolerite sills and dykes of the Ferrar Supergroup (Gunn and Warren, 1962; Kyle et al., 1981) (Figure 1).

Basement rocks exposed in the Ferrar/Koettlitz glaciers (west of AND-1B) and the Skelton to Byrd glacier sector of the TAM (south of AND-1B) show a wide range of lithological assemblages, metamorphic grade and granitoid fabrics.

In the Ferrar-Koettlitz glacier area, upper amphibolite-facies to upper greenschist-facies metamorphic rocks of the Koettlitz Group (Cook and Craw, 2001; Talarico et al., 2005) comprise dominant pure and impure marbles and calc-silicate rocks, interlayered with pelitic schists, paragneisses, amphibolites and minor amphibolitic schists (Williams et al., 1971; Findlay et al., 1984). These metasedimentary rocks are intruded by pre-, syn-, and postkinematic granitic and subordinate dioritic to gabbroic plutons, plugs, dykes and sills of the 510 to 480 Ma old Granite Harbor Intrusive Complex (Gunn and Warren, 1962; Allibone et al., 1993a). The Granite Harbor Intrusive Complex also contains a suite of late lamprophyric and felsic dykes (Allibone et al., 1993a, 1993b), and in the upper Koettlitz Glacier, alkaline granitoids and nepheline syenites, inferred to be associated with extension at 539-531 Ma (Cooper et al., 1997, and references therein).

To the southwest of the Mount Morning/Mount Discovery volcanic centers, in the Skelton Glacier-Mulock Glacier area, the lower greenschist to lower amphibolite metasedimentary rocks of the Skelton Group (Gunn and Warren, 1962; Cook and Craw, 2002) are intruded by minor alkaline-type quartz syenites and granites (Rowell et al., 1993) including a biotite \pm hornblende porphyritic variety (Teall Island and Mulock Glacier area) (Cottle and Cooper, 2006a; Carosi et al., 2007). The lower greenschist metasedimentary rocks consist of a variety of lithologies (Skinner, 1982; Cook, 1997, 2007; Cook and Craw, 2002) including white to grey metalimestones, metasandstones (including volcanoclastic varieties), quartzite, polymict metaconglomerate (carrying basaltic, rhyolitic and trachytic pebbles), and slightly deformed flows/ sills of trachyte, quartzo-syenite, or basaltic composition (Cook, 2007).

Higher grade metasedimentary rocks are restricted to limited exposures in the Cook Glacier and Mulock Glacier area where they include biotite \pm garnet or hornblende schists (occasionally injected by undeformed granitic veins), coarse-grained marbles, cordierite-biotite schists, epidote-biotite-actinolite schists, and diopside \pm scapolite granofelses (Cook, 1997, 2007; Cook and Craw, 2002). Exposures to the south between Mulock and Darwin glaciers are dominated by felsic granitoids (mainly post-tectonic granodiorites such as the Cooper Granodiorite, but also less extensive foliated porphyritic monzogranite) and minor mafic intrusions (e.g., Fontaine Pluton; Cottle and Cooper, 2006b). Further south, in the Britannia Range (between Darwin and Byrd glaciers), medium- to high-grade metasedimentary rocks (banded gneisses, schists with Ca-silicate layers, migmatites and minor amphibolite, marbles) and variably deformed (foliated to mylonitic) granitoids are common (Carosi et al., 2007). Metamorphic rocks are dominated by strongly deformed biotite \pm garnet and hornblende gneisses, often characterized by the occurrence of hornblendebearing leucosomes and migmatitic textures. Sequences of fine grained pelitic schists or two-mica gneisses, interlayered with rare actinolite-plagioclase-biotite schists and calc-silicate-fels locally occur. The metamorphic sequence is intruded, mostly concordantly by large amounts of pre- to syn-kinematic granodioritic to monzogranitic magma. Deformation in the granitoids is strongly heterogeneous and rare preserved igneous foliations are commonly overprinted by mylonitic gneissic textures, including thick greenschist-facies shear zones.

Figure 1. a) The Antarctic continent with present-day glacial flow lines (after Drewry, 1983; Barrett, 1999), location of McMurdo Sound (boxed) and of geological drill sites on land and on the Antarctic continental shelf. b) Geological map (after Craddock, 1970; Borg et al., 1989; Carosi et al., 2007). Also shown are the location of samples with petrographical features closely matching those of the AND-1B basement clasts (see also Figures 5-7). Present-day glacial flow lines of major outlet glaciers into the Ross Ice Shelf are after Fahnestock et al. (2000) and Drewry (1983) and inferred catchments are based on elevation data from Drewry (1983). Abbreviations: CG = Carlyon Glacier; TI = Teall Island; MM = Mount Morning; MiB = Minna Bluff; $\mathrm{MD}=$ Mount Discovery; BI = Black Island; WI = White Island; ME = Mount Erebus; MB = Mount Bird; MIS = McMurdo Ice Shelf. 

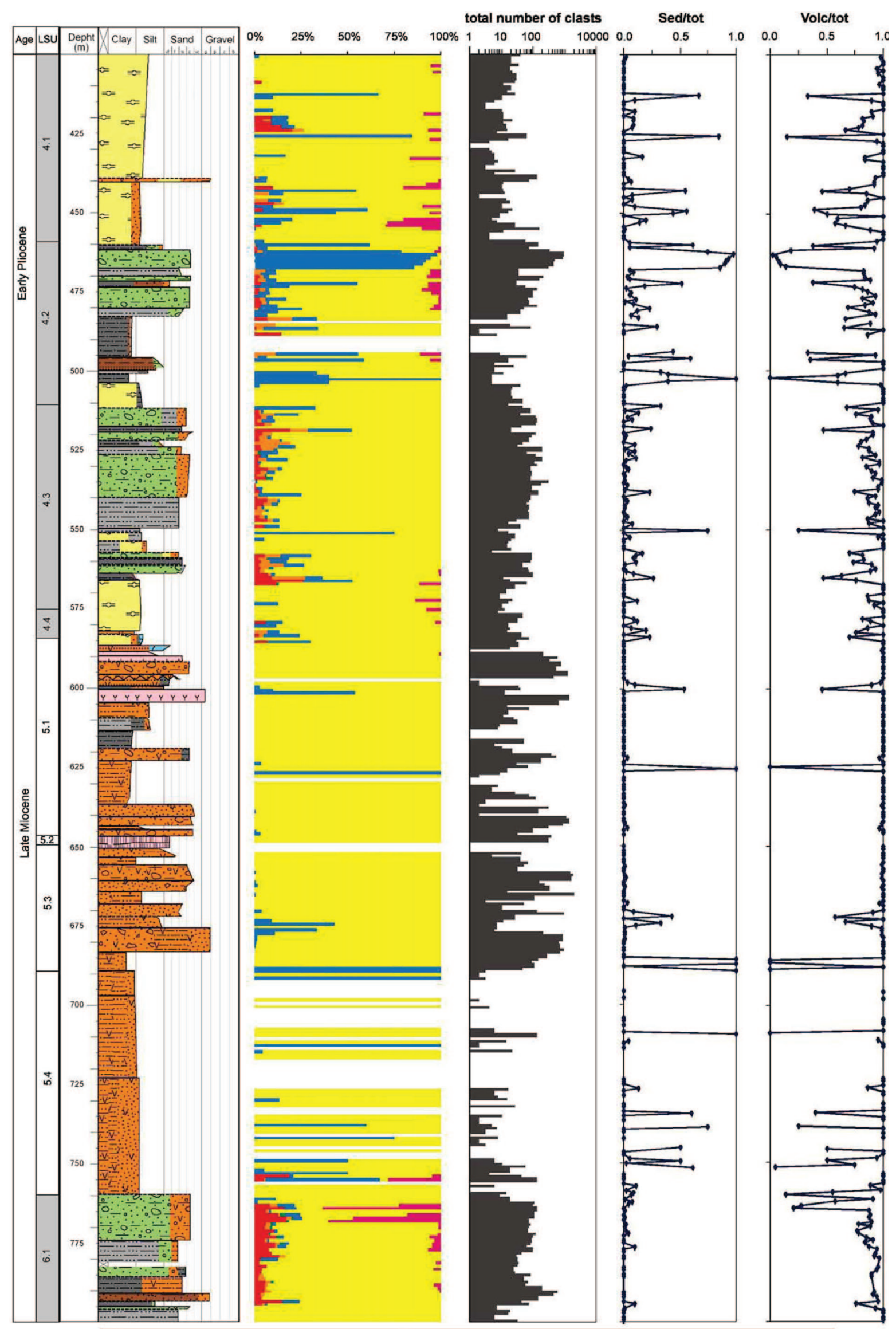

$\square$ INTRUSIVE ROCKS $\square$ QUARTZ $\square$ DOLERITES $\square$ SEDIMENTARY ROCKS $\square$ VOLCANIC ROCKS $\square$ METAMORPHIC ROCKS 


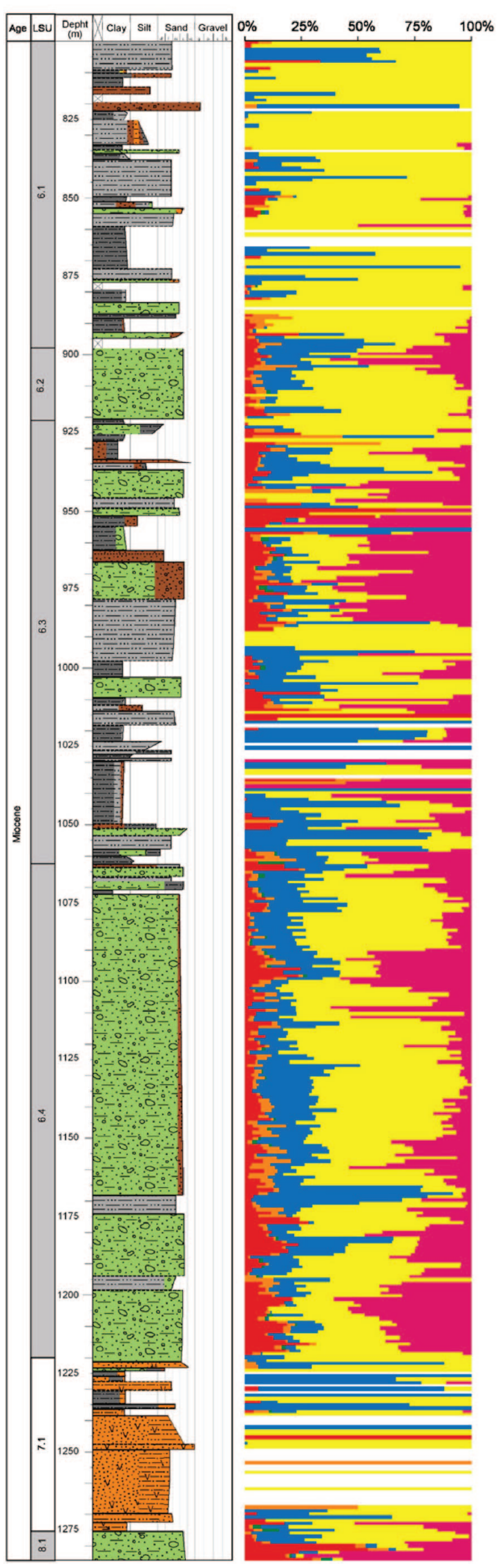

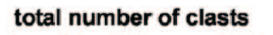

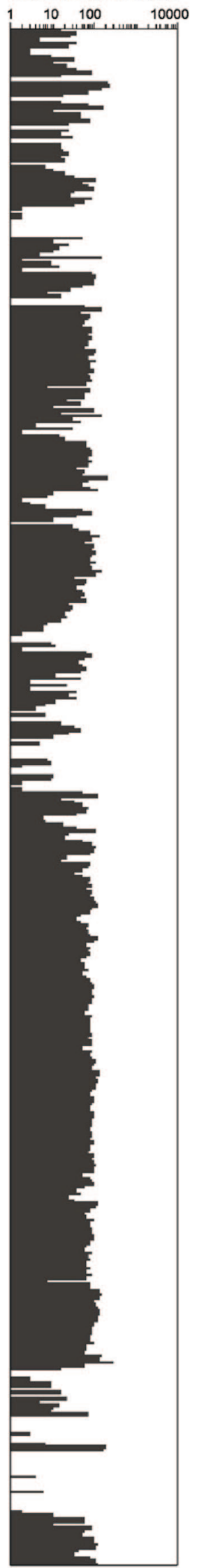

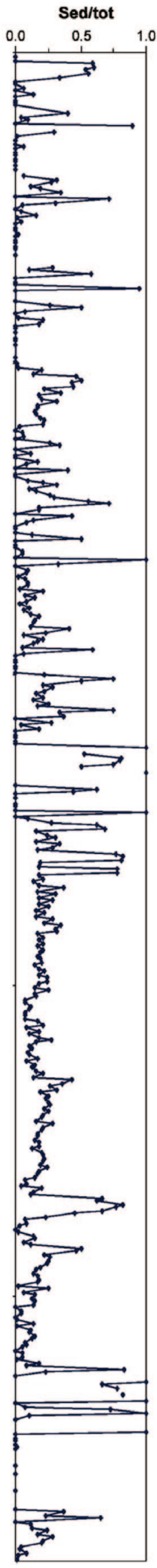

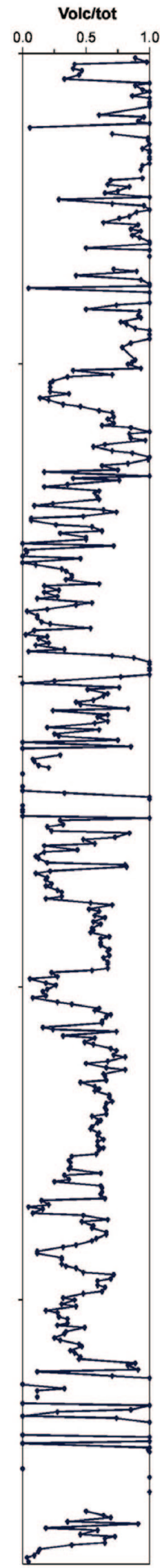

Figure 2. Lithostratigraphy and sequence stratigraphy of the lowermost $870 \mathrm{~m}$ of AND-1B core. Plotted alongside (left to right): clast compositions, clast abundance (average number of clasts per meter), ratio of sedimentary clasts to total number of clasts (Sed/tot) and ratio of volcanic clasts to total number of clasts (Volc/tot). Age intervals are based on the initial age model of Wilson et al. (2007a). Lithostratigraphy after Krissek et al. (2007). 
These lithological assemblages sharply contrast with the lowgrade metasedimentary rocks which include extensive exposures of metalimestone (Shackleton Limestone) and metaconglomerates (Byrd Group) (Grindley, 1963), in the region comprised between Byrd Glacier and Nimrod Glacier (Craddock, 1970; Stump et al., 2004) (Figure 1).

\section{AND-1B core: Chronostratigraphy, sequence stratigraphic framework, and previous provenance studies}

\subsection{Chronology and sequence stratigraphy}

The sedimentary succession cored in AND-1B was subdivided into nine chronostratigraphic intervals on the basis of major changes in lithology recognized during the initial phase of core characterization (Krissek et al., 2007), geochronological constraints (Wilson et al., 2007a), characteristic facies cycles, and their glacial and climatic signatures (Naish et al., 2007). At present, due to a relative lack of diatoms and primary volcanic ashes, the chronology below $759 \mathrm{mbsf}$ is constrained only by the ${ }^{40} \mathrm{Ar} /{ }^{39} \mathrm{Ar}$ age of a basaltic lava flow at 648.37 mbsf and of three separate volcanic clasts within a volcanic-glass-bearing diamictite at 1277.911279.04 mbsf which yielded a $13.57 \pm 0.13 \mathrm{Ma}$ age (Wilson et al., 2007a). This age has been interpreted as a maximum depositional age indicating that the Middle to Late Miocene is represented between 1285 and 759 mbsf in AND-1B, although comparison to the Pliocene interval suggests that there are probably numerous unconformities in this interval.

On the basis of characteristic facies, and through comparison to sedimentation in modern glacial environments from various climatic and glacial settings, Krissek et al. (2007) and McKay et al. (2009) identified three facies associations or sequence "motifs" that are interpreted as reflecting major changes in ice sheet volume, glacial thermal regime, and climate.

Sequence Motif 1 is documented in the Late Pleistocene (082.70 mbsf) and in the early Late Miocene (1083-1285 mbsf - except for the volcanogenic interval between 1275 and 1225 mbsf) sections and it is dominated by thick subglacial diamictite, deposited during glacial advance, with occasional thin interbeds of sparsely- to non-fossiliferous mudstone that marks an ice shelf setting during interglacial maxima. The near-absence of subglacial melt-water facies suggests that advance and retreat occurred under cold, polar conditions.

Motif 2 (Pliocene to Early Pleistocene) (82.70-586.59 mbsf) comprises subglacial to glacimarine diamictite overlain by thin, proglacial deposits and capped with substantial beds of diatombearing mudstone or diatomite formed under open-marine conditions. The marked fluctuation between ice-grounded and openmarine phases reflects advance and retreat under conditions warmer than Motif 1 ("sub-polar" to "polar" style of glaciations), a general absence of prolonged ice shelf conditions during interglacials, but still without significant subglacial melt-water.

Sequence Motif 3 (Late Miocene) (770-1083 mbsf) consists of subglacial diamictite that grades upwards into a 5- to $10 \mathrm{~m}$-thick proglacial retreat succession of stratified diamictite, graded conglomerate and sandstone, graded sandstone and/or rhythmically stratified mudstone. Thick mudstone intervals, rather than diatomite-dominated deposition during glacial minima, suggest increased input of melt-water from nearby terrestrial sources during glacial minima. Motif 3 represents "sub-polar" style glaciation with significant volumes of subglacially derived melt-water.

\subsection{Previous provenance studies on AND-1B core}

Preliminary work on basement clasts (Pompilio et al., 2007) qualitatively indicated that the provenance of clasts within massive diamictites interpreted as till in the AND-1B record was consistent with subglacial transport by glacial ice sourced from EAIS outlet glaciers of South Victoria Land (i.e., the region between Skelton and Byrd glaciers, to the south of the drill site). This compositional evidence indicates that the subglacially deposited sediments in AND-1B were the result of large-scale advance of grounded ice, rather than localized glacial advance from Ross Island or outlet glaciers in the McMurdo Sound region (Talarico et al., 2007).

Clast compositions and distribution patterns for intervals of the Late Pliocene to Pleistocene section corresponding to the uppermost $400 \mathrm{~m}$ of the AND-1B are described and discussed in Talarico et al. (submitted for publication). These petrological investigations also include the analysis of sand fraction compositional data and provided conclusive evidence of the Skelton/Mulock glacier catchments as the most likely source area, and the validity for the Late Pliocene/Pleistocene of a glaciological model similar to the configurations proposed by Drewry $(1979,1983)$, Kellogg et al. (1996), and Denton and Hughes $(2000,2002)$ for the grounded ice expansion within the McMurdo Sound during the LGM.

These results pointed out that changes in paleogeography related to the emergence of several volcanic centers during the deposition of the drill core succession were an important additional factor that could have altered the provenance signal. A major change in diamictite provenance was identified at $82.7 \mathrm{mbsf}$ coincident with the change in sedimentary cycle architecture, corresponding to the transition from the sub-polar Pliocene Motif 2 sequences to the polar-style Middle-Late Pleistocene Motif 1 glacial/interglacial cycles (Naish et al., 2007; McKay et al., 2009). The significance of petrological changes coupled with the sequence stratigraphical subdivision, the role of paleogeographic changes and the short-term cycle clast variabilities will be major aspects discussed in this paper and all relevant details of the Plio-Pleistocene section will be summarized in later sections as appropriate to allow a complete overview of provenance changes throughout the entire AND-1B sedimentary record.

\section{Methods}

Sampling, macroscopic observations and preliminary petrographical analyses were performed following the procedures for the Cape Roberts Project (CRP)-1 core (Cape Roberts Science Team, 1998a, 1998b). Identification of major lithological groups, clasts logging and the clast distribution analysis were organized adopting the same methodology adopted in CRP-2/2A and described in Cape Roberts Science Team (1999) and in Talarico et al. (submitted for publication).

Data processing involved the counting of all clasts per $1 \mathrm{~m}$ spaced intervals, subdivided in the different compositional groups. Only core intervals with high numbers of clasts $(>10$ per meter) were considered for analysis and discussion of clast distribution trends. Rocks from the Ferrar and Beacon supergroups are excluded from the "basement clast" class, which is herein used to refer only to extrabasinal clasts sourced from the pre-Devonian crystalline basement presently exposed in the TAM west and south of the AND-1B drill site.

Petrographical analysis of some basement clasts, consisting of several types of Ca-amphibole-bearing metamorphic rocks, also included the determination of mineral compositions using a Philips XL30 scanning electron microscope operating at $20 \mathrm{kV}$ and equipped with an X-ray energy dispersive system (SEM-EDS, at the Dipartimento di Scienze della Terra, Siena, Italy).

\section{Results}

\subsection{Lithological groups}

The AND-1B core gravel fraction can be investigated on the basis of a total of 95,112 clasts, that were counted and categorized into six main lithological groups including volcanic rocks, intru-

Figure 3. Down-core compositional variations in the gravel fraction in the lowermost $875 \mathrm{~m}$ of AND-1B core with respect to the hosting facies. The diagram shows the content of clasts in the different intervals for each facies. 
FACIES 1 - Diatomite

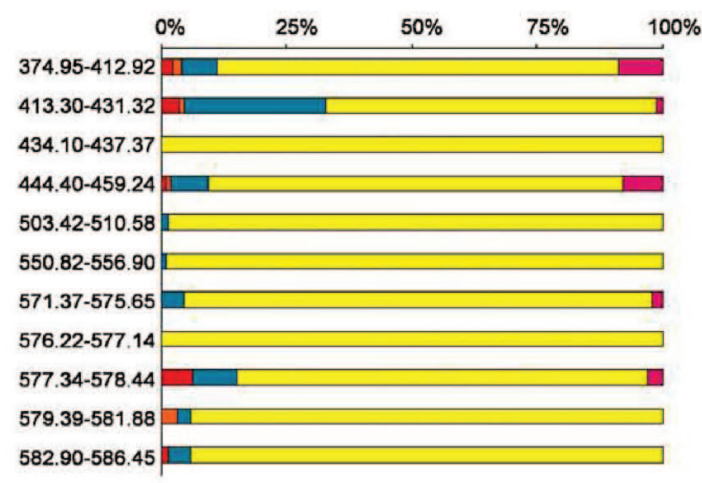

FACIES 3 \& 4 - Mudstone

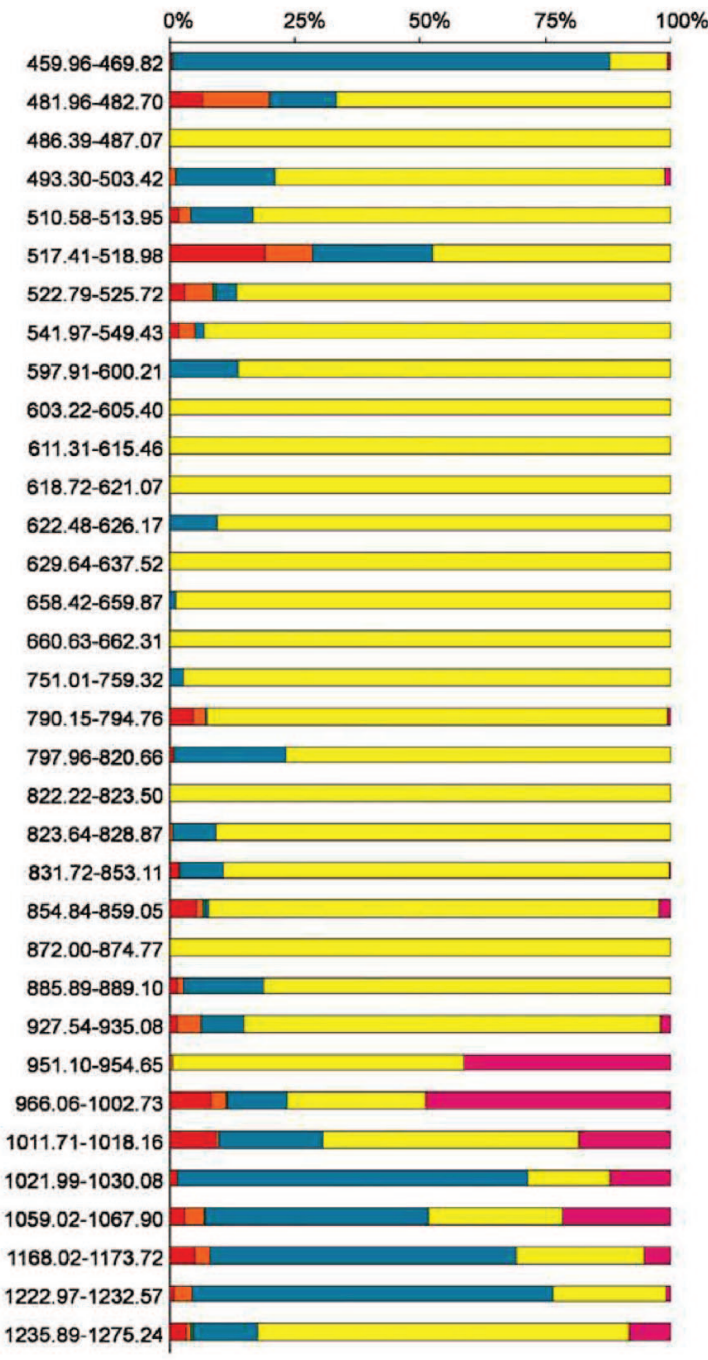

FACIES 2 - Massive mudstone

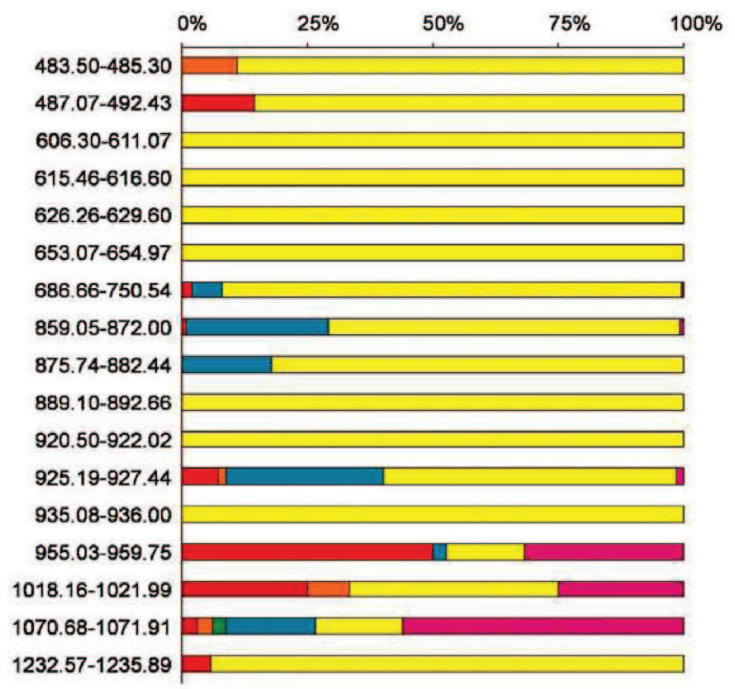

FACIES $9 \& 10$ - Diamictite

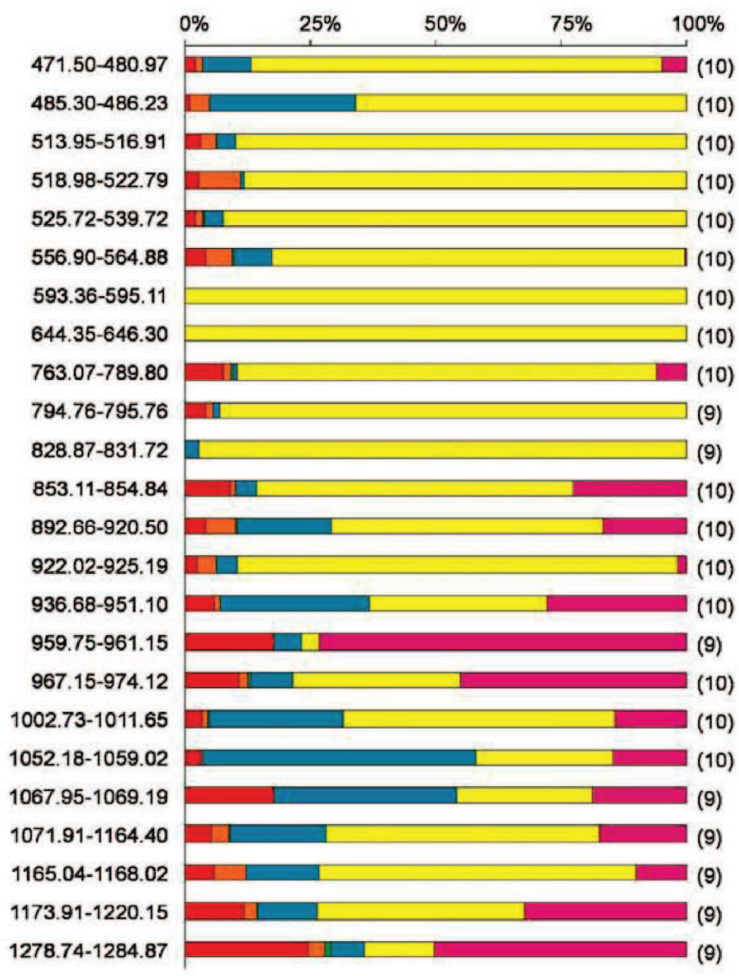

\begin{tabular}{|lll}
\hline intrusive rocks & $\square$ dolerites & $\square$ volcanic rocks \\
\hline quartz & sedimentary rocks & $\square$ metamorphic rocks
\end{tabular}

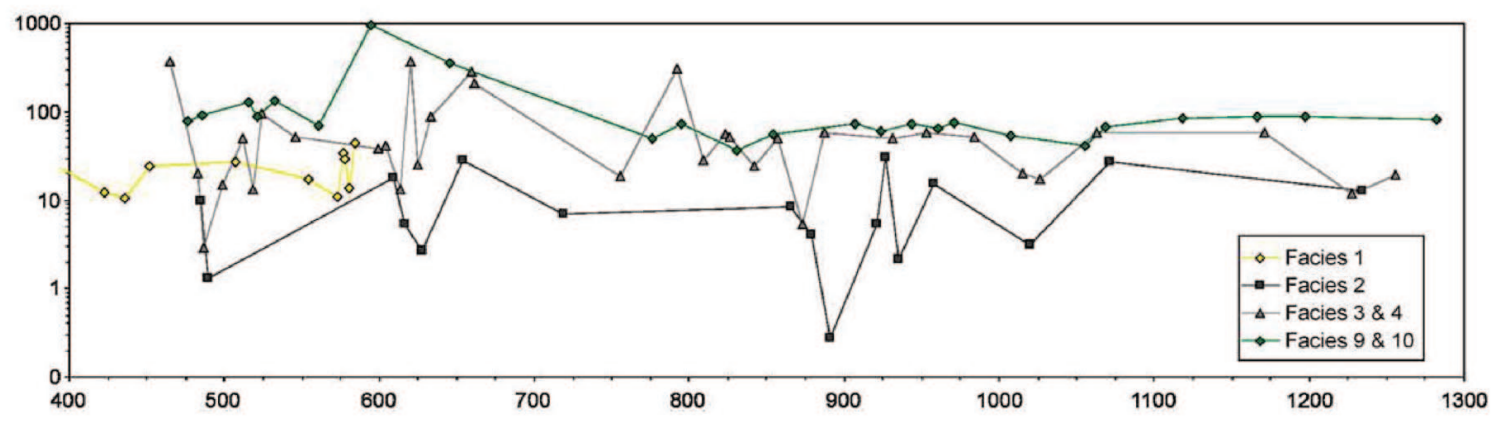


sive rocks, metamorphic rocks, sedimentary rocks, dolerites and quartz as defined in Pompilio et al. (2007) and in Talarico et al. (submitted for publication).

The volcanic rocks group is dominated by mainly subangular granules to small and medium-sized pebbles, that consist of a variety of aphyric to porphyritic varieties, some vesicular and/ or amygdale-bearing, and range in composition from mafic to intermediate and felsic. In several intervals the volcanic rocks have textural/mineralogical features typical of near-primary products (comprising dominant glassy lapilli and very angular to subrounded ash shards) (Pompilio et al., 2007; Di Roberto et al., 2008).

Intrusive and metamorphic rocks ("basement clasts") include a variety of rock types. Detailed petrographical data and distribution for those occurring below $400 \mathrm{mbsf}$ are described in Section 5.4. Compositional features of basement clasts above $400 \mathrm{~m}$ are reported in Talarico et al. (submitted for publication).

The most abundant intrusive rocks occur as pebbles and small cobbles of biotite with or without hornblende granitoids (e.g., granites, syenogranites, granodiorites) showing either isotropic fabrics or foliated to strongly mylonitic fabrics, with minor occurrence of deformed felsic porphyries and gabbroids. Granules, pebbles and cobbles of metamorphic rocks include a variety of low-grade metasedimentary rocks of various origin (metalimestones, metagreywackes, metasandstones) and metarhyolites scattered throughout the whole core; rare occurrences of biotite and cordierite, biotite-actinolite schists and marble are present above $400 \mathrm{mbsf}$ (Talarico et al., submitted for publication), and abundant clasts of migmatites, amphibolites and other medium- or highgrade rocks, mixed with low-grade metasedimentary rocks, are common below 1172 mbsf.

Sedimentary clasts mainly belong to the granule and small-pebble classes and consist of at least two major lithological types: a) quartz-arenites, likely sourced from the Beacon Supergroup, and b) intraformational clasts of poorly- to moderately-sorted sandstone with granule-grade clasts (reworked diamictites) and grey to black mudstone and minor sandstones.

Dolerites occur as granules to subrounded pebbles and cobbles and they are fine- or medium-grained with textural and mineralogical similarities to the Ferrar Dolerite.

Quartz occurs as granules or small pebbles, some of which have minor micas, and are most likely fragments of coarsegrained granitoids.

\subsection{Long-term compositional variability}

The distribution of clasts of the six lithological groups (as defined above) in the lowermost $875 \mathrm{~m}$ of the AND-1B core is summarized in Figure 2 in terms of their relative proportions using $1-\mathrm{m}$ spacing data. Figure 2 also shows the variability of the abundance of clasts, and the values of two ratios: number of sedimentary clasts/total number of clasts (Sed/tot) and number of volcanic clasts/total number clasts (Volc/tot). Since both sedimentary (mainly intrabasinal sediments) and volcanic clasts are most likely sourced within the same area of the drill site (or areas nearby), both ratios can provide a direct insight in the fluctuations of the contribution of local debris with respect to more distally sourced debris supplied from TAM outlet glaciers. Moreover the Sed/tot ratio can be also used as an index of reworking due to dominance of intraclasts (including clasts of diamictite) in the sedimentary clasts class.

Similarly to the Late Pliocene-Pleistocene section (Talarico et al., submitted for publication), volcanic rocks represent the ubiquitous and persistent lithology throughout the lowermost $875 \mathrm{~m}$ of the AND-1B core, constituting the prevailing rock type in the clast assemblages (up to $100 \%$ of the total number of clasts) in numerous and thick core intervals. In detail, clast compositions and abundances indicate the occurrence of three distinct petrofacies which suggest a first order subdivision of the investigated core section in six major intervals.

Petrofacies 1 (P1) (ca. 585-760 mbsf, LSU 5.1-5.3-5.4; ca. 12251275 mbsf, LSU 7.1) - dominated by volcanic clasts with variable, sometimes high, amount of intraclasts (average Volc/tot > 0.75) and very rare metasedimentary clasts (restricted to LSU 7.1).

Petrofacies 2 (P2) (ca. 400-585 mbsf, LSU 4.1-4.2-4.3-4.4; ca. 760-895 mbsf, LSU 6.1) - similar to 1, but with volcanic clasts associated to variable but always low contents of other lithologies (often more varied than in 1 with quartz/metamorphics/intrusive rocks).

Petrofacies 3 (P3) (ca. 895-1225 mbsf, LSU 6.2-6.3-6.4; ca. 12751284 mbsf, LSU 8.1) - basement clasts show a persistent occurrence with strong fluctuations of their relative proportions with respect to volcanic clasts, but they often constitute the dominant lithology in association to sedimentary clasts (average Volc/tot $<0.75$ ).

Petrofacies 2 extends upcore to 82 mbsf, and Petrofacies 3 occurs in the Late Pleistocene section above 82 mbsf (Talarico et al., submitted for publication). In the Petrofacies 1 interval between 585 and 760 mbsf, clast abundance allows a further distinction between the section below ca. 685 mbsf (LSU 5.4) mostly characterized by very low number of clasts and the section above $685 \mathrm{mbsf}$ (LSU 5.1-5.3) in which the average clast contents are high.

Among the three petrofacies, only Petrofacies 3 shows distinct internal patterns with prominent fluctuations of lithological proportions below 1000 mbsf, even within the single unit (e.g., the thick diamictite in LSU 6.4) and a clear up-core increase of volcanic clasts in the interval between 985 and 925 mbsf.

Dolerite clasts form a very subordinate and impersistent component throughout the lowermost $875 \mathrm{~m}$ of the AND-1B core, but with several occurrences mainly restricted to most diamictite units. Significantly higher contents were detected in the upper $80 \mathrm{~m}$ of AND-1B (Talarico et al., submitted for publication) where they are accompanied by a higher proportion of rounded quartz grains (many of which display overgrowths) which indicates a concomitant increased contribution from Devonian Beacon Supergroup (Taylor Group) sediments.

\subsection{Short-term compositional fluctuations and clast composi- tional variability with respect to the main lithological facies}

A number of high-frequency cycles are superimposed on the previously discussed long-term compositional patterns. These short-term changes in provenance are related to changes in sedimentary processes over the glacial/interglacial cycle, and we use the sequence stratigraphic model developed by Krissek et al. (2007) and McKay et al. (2009) to discuss these changes.

In the Pleistocene-Late Pliocene section (Talarico et al., submitted for publication), glacially derived diamicts have a strong Transantarctic Mountain provenance signal, while the composition of interglacial facies are dominated by local volcanic products (mainly primary deposits but also reworked felsic/intermediate lavas) and intraclasts, albeit a variable content of lonestones of basement lithologies, such as the distinctive low-grade metasedimentary rocks occurs as lonestones in diatomite facies, which point to a persistent involvement of the same provenance area identified for the diamictite units.

A similar compositional pattern is also typical of clasts distributed in the 30 glacial/ interglacial cycles identified in the Early Pliocene to Miocene section (Krissek et al., 2007; McKay et al., 2009). In the diatomite-diamictite cycles (i.e., above 585 mbsf; motif 2) glacial minima are documented within diatomite which systematically show lower numbers of clasts and less varied compositions with respect to associated glacial maxima sediments (Figure 3), a pattern which closely matches the one recognized in the section between 400 and 82 mbsf (Talarico et al., submitted for publication).

Figure 4. An example stratigraphic log of Motif 3 sequences as identified by McKay et al. (submitted for publication) in the 1000 to 1100 mbsf core section. Plotted alongside (left to right): clast compositions, clast abundance (average number of clasts per meter), ratio of sedimentary clasts to total number of clasts (Sed/tot) and ratio of volcanic clasts to total number of clasts (Volc/tot). Glacial proximity abbreviations: M marine; D ice distal; P ice proximal; I ice contact/subglacial. 


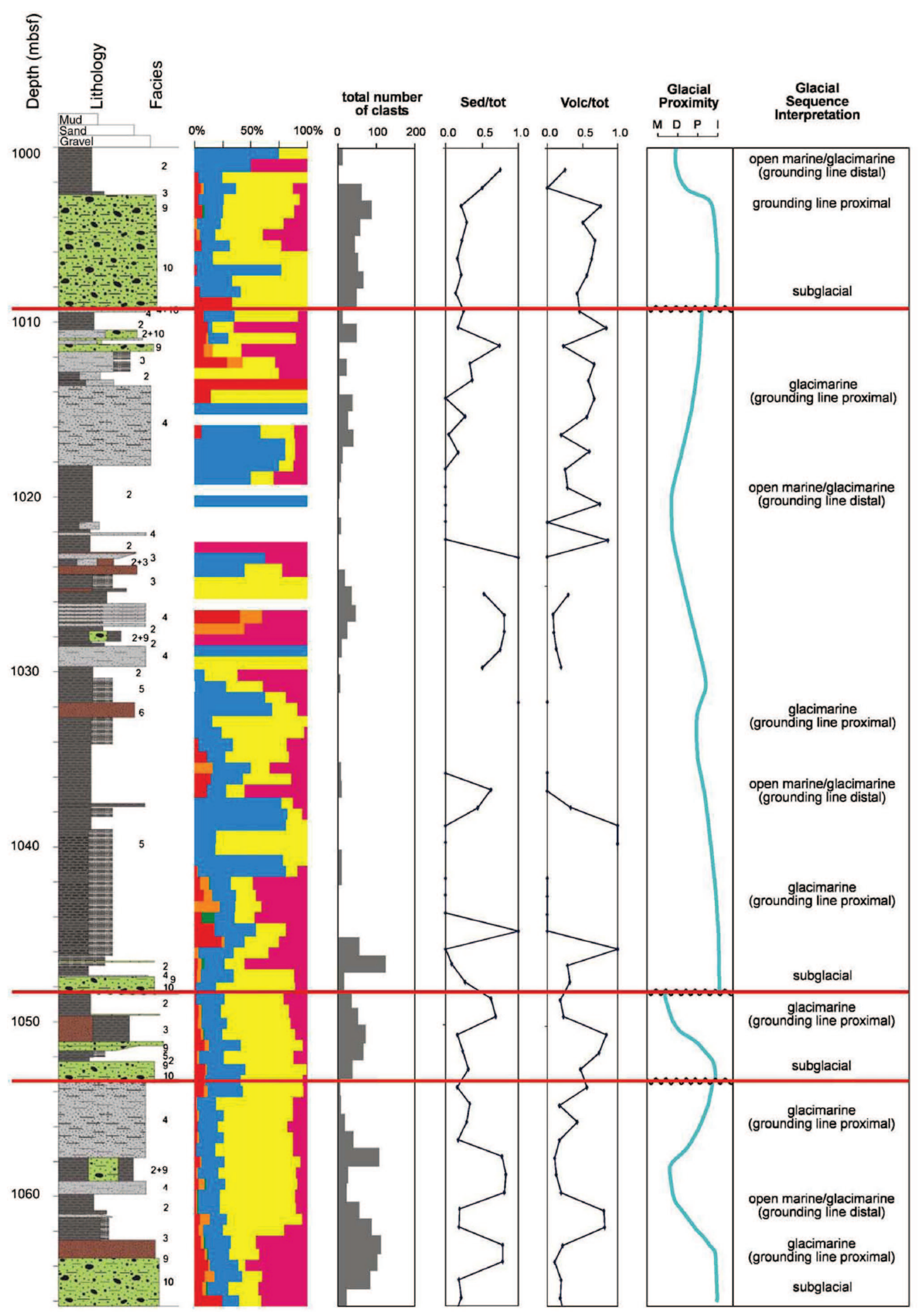


Similar compositional differences are also evident in the mudstone-diamictite cycles (between 775 and 1083 mbsf, motif 3) (Figure 4), and further down-core in the Motif 1 diamictite-dominated sections at 1083-1168 mbsf and 1275-1285 mbsf.

Additional information on clast distribution patterns and glacial/interglacial cycles is provided by the analysis of clast compositional variability with respect to the main lithological facies (Figure 3). The number of clasts per meter length throughout the investigated core section is highly variable, ranging from $<10$ counts $/ \mathrm{m}$ in the mudstone facies, characterized by the lowest clast contents, to several hundred counts per meter in diamictite intervals. Core intervals particularly rich in clasts (> 200 clasts $/ \mathrm{m}$ ) are mainly concentrated in the 550-750 mbsf section, where they occur in both mudstone and diamictite facies and show volcanic clasts-dominated assemblages. In diamictite facies, clast compositions are dominated by volcanic clasts with variable and low contributions of other lithologies in the interval between ca. 200 and 900 mbsf, and with more varied assemblages enriched in basement clasts in the remaining part of the cores. A similar core partition is suggested by mudstone dominated facies 3 and 4 but with a ca. $100 \mathrm{~m}$ down-core shift of the boundaries. Massive mudstone facies show clast assemblages dominated by volcanic clasts with subordinate contents of sedimentary clasts or quartz or intrusive rocks, a part from some intervals between 950 and 1075 mbsf, where basement clasts, including a significant proportion of metamorphic rocks, are the prevailing component.

Rhythmically interlaminated mudstone/siltstone/sandstone facies (facies 5 in Krissek et al., 2007) is restricted to a thin core section (at ca. 1030-1046 mbsf); clasts are very few $(3 / \mathrm{m})$ but they include different basement rock types, intraclasts and volcanic clasts. Sandstone facies is more common, with six occurrences all within the 598-884 mbsf core section and dominated by volcanic clasts and variable clast contents (from 2 to ca. 6900 clasts/m). A similar volcanic clast-rich assemblage occurs in conglomerate facies (at ca. 820.66-821.73 and 1220.55-1222.97 mbsf), whereas intraformational sedimentary clasts, rarely associated to other lithologies, and highly variable clast abundances (up to 200 clasts/m) are common in the breccia facies (at 437.37-440.12, 639.45-640.33, 662.31-663.34 and 872.51-875.74 mbsf).

\subsection{Petrography of basement clasts and provenance inferences}

In the Early Pliocene-Miocene section of the AND-1B core, 218 samples of pebble- to cobble-sized basement clasts, representative of all lithological types, were collected and investigated using a petrological microscope. Table 1 shows the distribution of all identified rock types for each LSU together with the wide range of lithologies already described by Talarico et al. (submitted for publication) for the Pleistocene-Late Pliocene section (114 samples).

All samples are cobble or pebbles of appropriate size to allow a complete petrographic analysis using a standard thin section and are mainly from diamictite units (facies 10 and 9) and from facies (3) (mudstone with dispersed clasts, as defined and logged by Krissek et al., 2007). Very rare samples were collected from clast-poor facies such as diatomite and mudstone. The most common lithologies are monzogranite and low-grade metasedimentary rocks in both facies (Table 1) and the low number of sampled clasts mainly reflects their primary low abundance. No samples are available from the core section at 575-750 mbsf (LSU 4.4, 5.1, 5.2, 5.3 and 5.4) which is devoid of basement clasts and mainly consists of lapilli tuff and tuff breccia beds interpreted by Di Roberto et al. (2008) as the result of primary volcanic submarine processes originating from a very close volcanic system.

Clast logging and petrographical data allow a subdivision of the core into 1) a section above 1172 mbsf, where several lithologies already reported for the uppermost $400 \mathrm{~m}$ (Talarico et al., submitted for publication) represent a persistent occurrence, and 2) a section below 1172 mbsf in which these lithologies are minor or absent whereas gneisses (including migmatitic varieties) and muscovite-bearing monzogranites constitute a new distinctive clast assemblage.

\subsubsection{Basement clasts above $1172 \mathrm{mbsf}$}

The most common basement clasts above 1172 mbsf include granitoids (dominant isotropic or foliated biotite granites and biotite-hornblende syenogranites and granodiorites), low-grade metasedimentary rocks (dominant biotite \pm calcite \pm Ca-amphibole metasandstones, biotite slates/phyllites, metalimestones), contact metamorphosed metasandstones, amphibole-plagioclase granofelses, metabasalts and metarhyolites (Figure 5). Several other rock types (Table 1) show a more limited occurrence. They comprise several types of intrusive rocks ranging in composition from felsic (i.e., biotite-hornblende tonalite, biotite-hornblende alkali feldspar granite) to intermediate and mafic (i.e., isotropic or foliated biotite-hornblende quartzo-diorite and gabbro). In some samples heterogranular/porphyric textures are indicative of rather low emplacement depths suggesting a derivation from shallow intrusions or dyke swarms (e.g., microgranites, granophyres) (Figure 6).

Commonly observed mineral assemblages in the metasedimentary rocks include: biotite - muscovite \pm calcite + actinolite, i.e., a paragenesis diagnostic of greenschist-facies conditions (Bucher and Frey, 1994). Detrital mineral grains of quartz, plagioclase, cherts and muscovite are common. Most samples show a cleavage defined by biotite and sericite. Some samples are characterized by a mm-scale compositional layering, a well developed crenulation cleavage, or they show a diagenetic foliation (Passchier and Trouw, 1996) defined by the preferred alignment of detrital white mica grains and partially overprinted by a weak cleavage defined by sericite and very fine grained biotite. In the amphibolebearing rocks, actinolite nematoblasts are always randomly oriented suggesting a static growth, most likely as result of contact metamorphism.

Comparison with the main rock units exposed in the Ross Orogen in SVL indicate that clast assemblages including pebbles of low-grade metamorphic rocks and of heterogranular/porphyric granitoids mirror the lithological assemblages of the Skelton Group (Grindley and Warren, 1964) in restricted outcrop areas between the Skelton and Mulock glaciers, about $100 \mathrm{~km}$ southwest of the AND-1B drill site (Figures 1, 5, \& 6). As shown in Figure 5 and Figure 6 the petrographical characteristics of these clasts closely match the mineralogical and textural features of several major lithologies which are exclusive in most outcrops in the Teall Island-Mulock Glacier area, as recognized and mapped by several authors (Skinner, 1982; Cook, 1997, 2007; Cook and Craw, 2002; Carosi et al., 2007).

For example the coexistence of pebbles of several basement rock types within short core intervals (i.e., $<1 \mathrm{~m}$ thick) including metalimestones, metabasalts and metarhyolites and strongly heterogranular granitoids (e.g., LSU 6.3) indicate a provenance from a specific a compositionally similar assemblage that is exposed in the northern part of Teall Island (Carosi et al., 2007) and potentially in other unexposed areas near the Skelton Glacier.

In most metasandstones and amphibole-bearing granofelses, randomly oriented Ca-amphibole blasts and decussate textures overprint previously formed cleavages defined by finer grained white micas. These fabrics are indicative of static transformations which very likely occurred during a local contact metamorphic event. Similar lithologies and fabrics were described by Skinner (1982) around the main intrusions in the Skelton Glacier area and were more recently resampled by the first author during field activity and mapping in the region (Carosi et al., 2007).

In the lowermost part of the section granitoids (including both isotropic and foliated varieties, Figure 6) indicate a possible southerly shift of provenance providing evidence for the involvement of areas located ca. $30 \mathrm{~km} \mathrm{~S} \mathrm{of} \mathrm{the} \mathrm{Mulock} \mathrm{Glacier,} \mathrm{along} \mathrm{the} \mathrm{north}$ side of the Carlyon Glacier (Figure 1). 


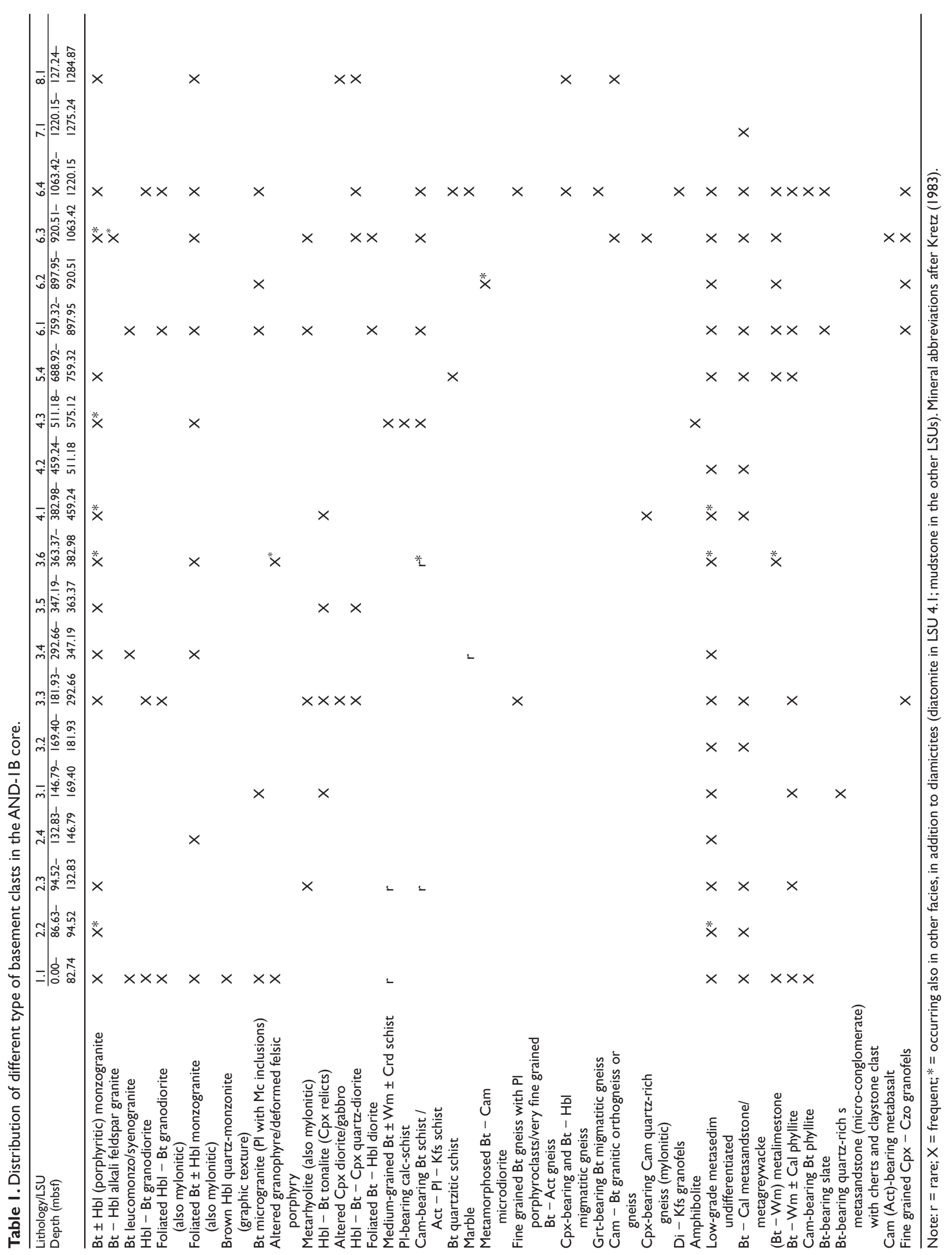



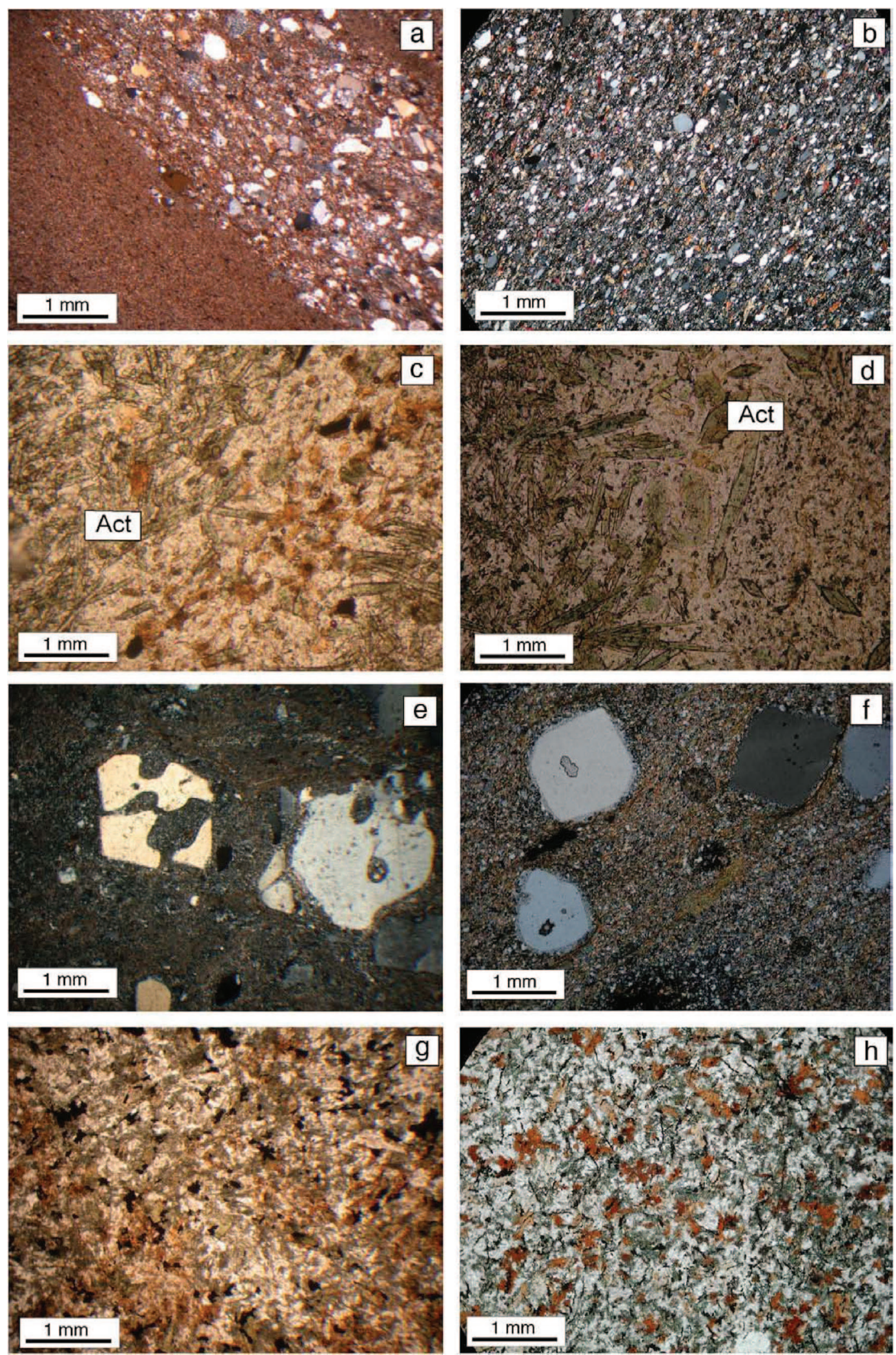

Figure 5. Microphotographs showing examples of representative pebbles of low-grade metamorphic rocks (left column) and of petrographically similar lithologies (right column) from the Skelton-Mulock glacier region (see Figure 1 for their location), the region identified as including the source outcrops for basement clasts throughout the lower Pliocene-Miocene AND-1B core section. (a) and (b) - Biotite-bearing metasandstone. a) Clast 1078.50 mbsf, (crossed polarizers). b) Sample 2116T2 (Teall Island) (crossed polarizers). (c) and (d) - Actinolite-bearing biotite-plagioclase granofels. c) Clast 558.64 mbsf (plane-polarized light). d) Sample 17123FR13 (lower Skelton Glacier) (plane-polarized light). (e) and (f) - Metarhyolite: quartz and microcline phenocrystals are set in a recrystallized groundmass with neoblastic biotite. e) Clast 780.47 mbsf (crossed polarizers). f) Sample 17123FR26 (Teall Island) (crossed polarizers). (g) and (h) - Metabasalt retaining a sub-ophitic texture with laths of plagioclase and interstitial mafic minerals (mainly secondary: actinolite, chlorite, biotite and opaque minerals). g) Clast 961.44 mbsf (plane-polarized light). h) Sample 2116T4B (Teall Island) (plane-polarized light). 

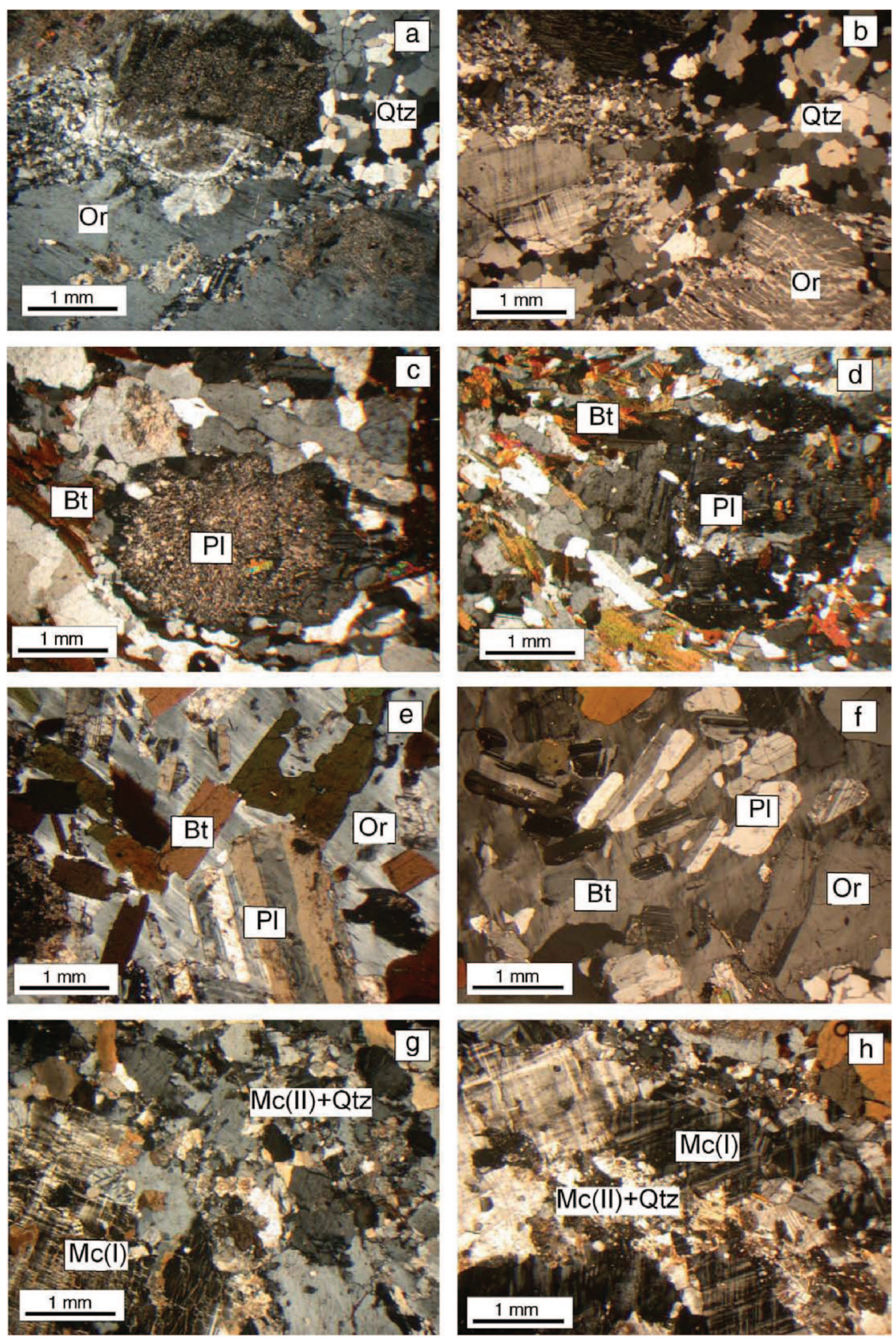

Figure 6. Microphotographs showing examples of representative pebbles of felsic intrusive rocks (left column) and of petrographically similar lithologies (right column) from the Skelton-Darwin glacier region (see Figure 1 for their location) (crossed polarizers). (a) and (b) - Porphyric monzogranite: phenocrystals of K-feldspar (Kfs) are set in a fine grained quartz-rich matrix. a) Clast 719.14 mbsf. b) Sample 2116F6 (lower Skelton Glacier). (c) and (d) - Foliated biotite granodiorite: a strained plagioclase (Pl) porphyroclast is warped by a marked foliation defined by biotite and recrystallized quartz. c) Clast 1145.84 mbsf. d) Sample 2116F10 (Carlyon Glacier area). (e) and (f) - Heterogranular biotite monzogranite: orthoclase (Or) with abundant inclusion of plagioclase (Pl), in sub-euhedral laths, and biotite (Bt). e) Clast 1167.91 mbsf. f) Sample 2416F9B (Carlyon Glacier area). (g) and (h) - Mylonitic monzogranite: strained microcline (Mc-I) porphyroclasts are surrounded by subpolygonal granoblastic aggregates of neoblastic microcline and quartz (Mc-II + Qtz). g) Clast 1186.38 mbsf. h) Sample 2416F14 (Darwin Glacier). 

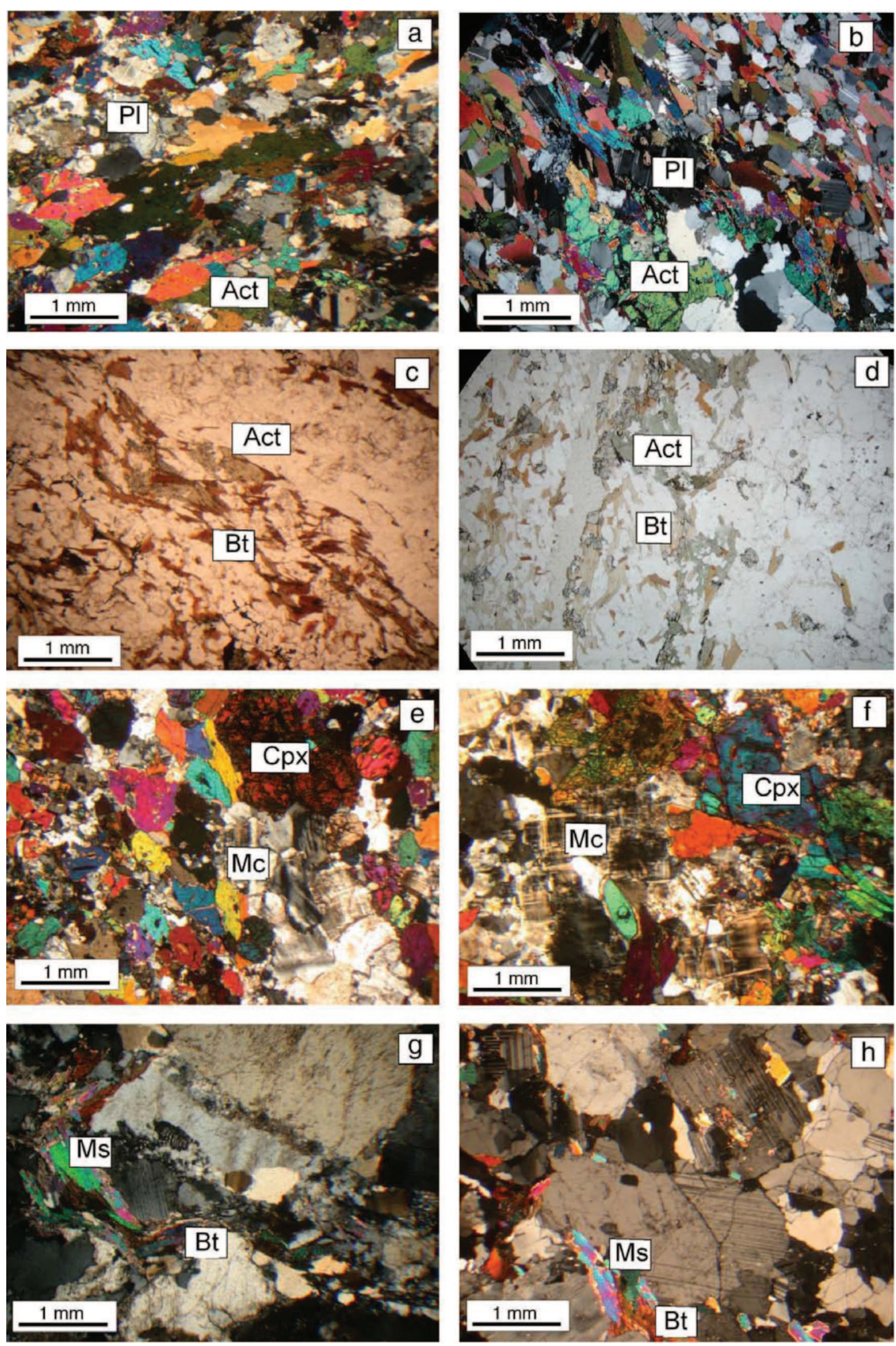

Figure 7. Microphotographs showing examples of representative basement clasts (left column) and of petrographically similar lithologies (right column) from the Carlyon-Byrd glacier region (see Figure 1 for their location), the region identified as including the source outcrops for basement clasts with occurrences restricted to the lowermost section of the AND-1B succession (below 1172 mbsf). (a) and (b) - Actinolite-plagioclase schist. a) Clast 1217.41 mbsf, (crossed polarizers). b) Sample $1916 \mathrm{T13}$ (lower Byrd Glacier area) (crossed polarizers). (c) and (d) - Actinolite-bearing biotite-plagioclase fine grained gneiss. c) Clast 1189.63 mbsf (plane-polarized light). d) Sample 18106T14 (Darwin Glacier area) (plane-polarized light). (e) and (f) - Clinopyroxene-microcline granofels. e) Clast 1195.70 mbsf (crossed polarizers). f) Sample 1816F7 (Darwin Glacier). (g) and (h) - Two mica monzogranite: biotite (Bt) and muscovite (Ms) flakes define a weak foliation. g) Clast 1280.04 mbsf (crossed polarizers). h) Sample 2016F4 (Byrd Glacier area) (crossed polarizers). 


\subsubsection{Basement clasts below $1172 \mathrm{mbsf}$}

The distinctive assemblage of low/ medium- to higher-grade metamorphic clasts occurring below 1172 mbsf include actinoliteplagioclase-K-feldspar schists, very fine grained biotite-actinolite gneisses, diopside-K-feldspar granofelses and biotite and/or hornblende-bearing migmatitic gneisses. Mineral assemblages of the actinolite-bearing rocks indicate greenschist grade conditions, whereas the diopside-K-feldspar paragenesis and migmatitic textures are indicative of higher grade, amphibolite-facies conditions (Bucher and Frey, 1994). As shown in Figure 7, potential source rocks for these pebbles can be identified in the region between Carlyon Glacier and Byrd Glacier (Figure 1), where assemblages of interlayered greenschist and amphibolite grade metamorphic rocks with similar mineral compositions and textures have been reported by Carosi et al. (2007).

\subsubsection{Provenance inferences based on Ca-amphibole compositions and geothermobarometry}

The occurrence of amphibole-bearing metamorphic rocks throughout the AND-1B core allows the determination of $P-T$ conditions prevailing during the metamorphic evolution in the source rock units, thus providing an additional tool to further constrain the provenance of basements clasts in AND-1B core. Five representative samples were selected for mineral chemistry investigations and geothermobarometric estimates (Table 2).

Samples TAL44.13 and TAL534.93 are a contact metamorphosed amphibole-bearing metasandstone and an amphibolebiotite-plagioclase hornfels, respectively. In TAL44.13 amphibole (actinolitic hornblende, $\left.X_{\mathrm{Mg}}=\mathrm{Mg} /\left(\mathrm{Mg}+\mathrm{Fe}^{\prime \prime}\right)=0.79\right)$ occurs as poikilitic euhedral blasts, randomly oriented and overprinting a cleavage defined by biotite $\left(X_{\mathrm{Mg}}=0.46, \mathrm{TiO}_{2}=0.59\right.$ wt. \% $)$ and plagioclase $(\mathrm{An}=0.59-0.74)$ (amphibole classification after Leake et al., 1997). TAL534.93 is fine grained and consists of amphibole, occurring as larger porphyroblasts (Mg-hornblende to actinolite $\left.X_{\mathrm{Mg}}=0.79-0.82\right)$ and finer grained nematoblasts with similar compositions and associated with biotite $\left(X_{\mathrm{Mg}}=0.46\right.$, $\left.\mathrm{TiO}_{2}=0.59 \mathrm{wt} . \%\right)$ and plagioclase (an $\left.=0.87-0.90\right)$ in the matrix.

Sample TAL 1217.41 is a medium-grained actinolite-plagioclase schist and sample 1189.63 is a fine grained biotite-amphibole paragneiss showing a compositional layering defined by Ca-amphibole + biotite-rich and plagioclase-rich layers.

Sample 1187.51 is a hornblende-bearing migmatitic gneiss characterized by a thin hornblende-rich mesosome (carrying relics of clinopyroxene) and an almost completely recrystallized leucosome of granitic composition.

Results of the application of the empirical Ca-amphibole geothermobarometry using the analytical expressions given by Zenk and Schulz (2004) and Gerya et al. (1997), which are designed for Ca-amphibole and plagioclase compositions with anorthite contents $>0.10$, are listed in Table 2 . The two methods gave similar $T$ results; P calculated with Zenk and Schulz (2004)'s geobarometer are 0.1-1.1 kbar higher than those obtained using the Gerya et al.
(1997) barometer. Absolute errors in both methods are $\pm 1.2 \mathrm{kbar}$ and $\pm 37^{\circ} \mathrm{C}$.

The amphibole compositions in four of the five samples (TAL44.13, TAL534.93, 1217.41 and TAL1189.63) record similar low $T$ and $P$ values of ca. $400-500{ }^{\circ} \mathrm{C}$ and ca. $2-3$ kbar, whereas the hornblende in the migmatitic gneiss retain compositions indicative of higher $P$ and $T$ conditions $\left(600^{\circ} \mathrm{C}, 5 \mathrm{kbar}\right)$, similar to $P T$ estimates obtained in a petrographically comparable gneiss (12T4) from the Darwin Glacier area (Figure 1, Table 2).

In samples TAL44.13 and TAL534.93, the estimated T estimates, at the boundary between low- and medium grade conditions, low $P$ values and decussate fabrics are all consistent with the occurrence of a contact metamorphic overprint. A distinctive mineralogical feature in the investigated sample is the coexistence of actinolite with Ca-rich plagioclase. A metamorphic zone characterized by the actinolite-calcic plagioclase assemblage has been known to exist in the contact aureoles in several areas (e.g., Sierra Nevada: Loomis, 1966) and defined as a distinct metamorphic facies, the "actinolite-calcic plagioclase hornfels facies" of Miyashiro (1961). Similar metamorphic conditions are reported by Skinner (1982) and by Cook and Craw (2002) in the country rock of the main intrusions in the Skelton-Mulock glacier area.

Interestingly samples TAL 1217.41 and TAL1189.63 show similar $P-T$ values but their granolepidoblastic fabrics are typical of dynamic recrystallization. Similar samples were collected from greenschist-facies shear zones by Carosi et al. (2007) N of Darwin Glacier (Brown Hills) and from other areas in the Britannia Range (unpublished data).

Additional work is needed to further investigate the comparison between clasts and potential source rocks, and a compilation of existing mineral chemistry data in a regional database is in progress to help in the comparisons. Despite these limitations, the PT data are consistent with the qualitative constraints based on diagnostic mineral assemblages and metamorphic structures, and they confirm the provenance of AND-1B metamorphic clasts from source regions with overall characteristics closely matching the metamorphic pattern of the Ross Orogen as exposed in the region between the Skelton Glacier and the Byrd Glacier.

\section{Discussion and conclusions}

The gravel fraction in the AND-1B core provides evidence of an evolving provenance that reflects the role, most likely in combination, of several factors including paleogeographic changes, changes in the ice flow patterns and ice volume modifications as result of regional scale processes (i.e., different contribution of EAIS and WAIS) or glacial/interglacial climatic cycles.

In the following sections, clast variability and provenance data are summarized and discussed to preliminarily assess the influences of the different factors. Although a few aspects require further investigations to corroborate the interpretations, the results have significant implications for the reconstruction of the Late Ce-

Table 2. Results of Ca-amphibole geothermobarometry for Ca-amphibole bearing metamorphic rocks occurring as pebbles in AND-IB core (TAL 44.13, 534.93, I I87.5I, II89.63 and I2I7.4I).

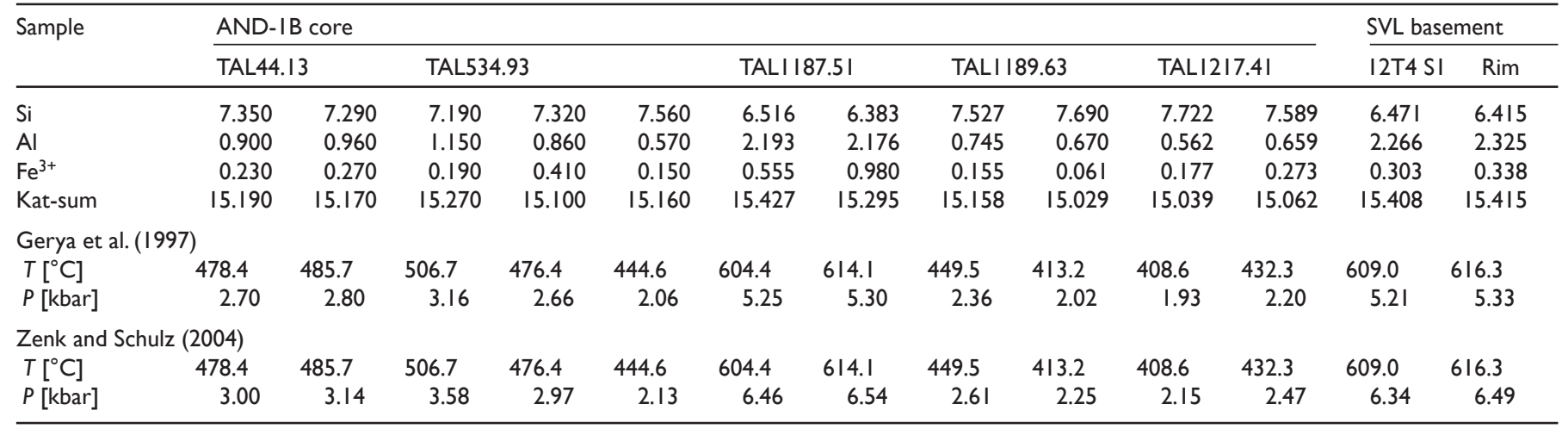

Sample I2T4 (Byrd Glacier region, see Figure I for location) is included for comparison (see text for discussion).

Note: Each analysis is average of at least 3 analytical spots from a single compositionally homogeneous crystal. 
nozoic glacial evolution in the Ross Embayment and they can be conveniently discussed in the context of LGM glaciological scenarios (e.g., Denton and Hughes, 2000, 2002), and of numerical ice sheets models (e.g., Huybrechts, 2002; Pollard and DeConto, 2009).

\subsection{Long-term provenance shifts}

Analysis of clast compositions and abundances throughout the entire core indicates that the long-term shifts in compositional patterns reflect the distribution of three petrofacies which divide the sedimentary succession into 6 major intervals, including from the bottom to the top (Figure 8):

ca. 1275-1284 mbsf (Late Miocene) (Petrofacies 3): clast assemblages include persistent basement clasts and volcanic rocks showing strong fluctuations of their relative proportions, with basement clasts often representing the dominant lithology in association to sedimentary clasts (average Volc/tot $<0.75)$.

ca. 1225-1275 mbsf (Late Miocene) (Petrofacies 1): dominated by volcanic clasts with variable, sometimes high, amounts of intraclasts (average Volc/tot $>0.75$ ) and very rare metasedimentary clasts.

ca. 895-1225 mbsf (Petrofacies 3): as above but with prominent fluctuations of lithological proportions below $985 \mathrm{mbsf}$, and a clear up-core increase of volcanic clasts in the interval between 985 and 925 mbsf. A further subdivision is based on the petrography of metamorphic basement clasts that indicate a shift from Byrd Glacier-Darwin Glacier sourced debris (below 1172 mbsf) to Skelton sourced debris (above 1172 mbsf).

ca. 760-895 mbsf (Petrofacies 2): similar to petrofacies 1, but with volcanic clasts associated to variable but always low contents of other lithologies (often more varied than in P1 with quartz/metamorphic/intrusive rocks).

ca. 585-760 mbsf (Late Miocene): similar to the ca. 1225-1275 mbsf interval (i.e., Petrofacies 1), with very low number of clasts below ca. 685 and high average clast contents.

ca. 82-585 mbsf (Pliocene-Late Pleistocene): with clast distribution patterns and assemblages similar to those described for the ca. 760-895 mbsf interval (Petrofacies 2).

0-82 mbsf (Late-Middle Pleistocene): with clast distribution patterns and assemblages similar to those described for the ca. 1275-1284 mbsf interval (Petrofacies 3).

In the Pleistocene-Late Pliocene core section Talarico et al. (submitted for publication) pointed out a major change in diamictite provenance at $82.70 \mathrm{mbsf}$ (corresponding to the transition from P2 to P3 in this study). This is coincident with a change in sedimentary cycle architecture that has previously been interpreted as representing the transition from sub-polar conditions, warmer than present, to the modern style of cold polar ice sheet (Naish et al., 2007; McKay et al., 2009).

This provenance shift in AND-1B core probably reflects important differences in the dispersion processes of sediments and in the erosional patterns which were active during each regime.

However, changes in paleogeography - related to the regional volcanic evolution - can represent an important additional factor that might have strongly influenced the sediment provenance and complicated the climatic signal.
The down-core distribution of petrofacies and petrological boundaries (as summarized above and shown in Figure 8) demonstrate that the Early Pliocene to Late Miocene section further corroborate this conclusion. Figure 8 also includes three paleogeographic scenarios showing reconstructed pathways for ice sourced from the southern TAM outlet glaciers into the AND-1B drill site during glacial expansion in the Late Pleistocene, the Pliocene and the Miocene.

Petrofacies 2 (typical of the motif 2 sequences in the Pliocene section) further extends in the upper part of Motif 3 sequences. Petrofacies 3, identified in the Motif 1 sequences in the Pleistocene section, is also associated to Motif 1 sequences identified by McKay et al. (2009) in the Late Miocene section, but the petrological boundary occurs within Motif 3 sequences, ca. $90 \mathrm{~m}$ above the motif boundary (at 1083 mbsf according to McKay et al., 2009).

The shifts from Petrofacies 3 to Petrofacies 1 or 2 and vice versa, their repetition in the succession and clast provenance from source areas S of Minna Bluff are difficult to be explained as reflecting a simple unroofing-erosional process as a consequence of the uplift of a single crustal block including basement and Cenozoic volcanic rocks and close to the drill site area (e.g., in the Royal Society Range in the Koettlitz Glacier area).

In the Victoria Land Basin, the role of tectonic controls over clasts compositions was put forward by Talarico et al. (2000) and Smellie $(2000,2001)$, but in older sediments within the lower Miocene to Oligocene record recovered at CRP-3 and CRP-2 drill sites.

This is not a surprise since the so far documented TAM uplift episodes are confined within a time window which is definitely older (i.e., between 55 and $15 \mathrm{Ma}$ ) than the AND-1B core record (Fitzgerald, 2002). However, tectonic activity is still ongoing within the McMurdo Sound area, as shown by the widespread McMurdo Group alkaline volcanism and minor faulting in the Quaternary (Jones 1997). The "Discovery accommodation zone", a prominent structural corridor associated with the major offset of the TAM rift flank in southern Victoria Land (Wilson, 1999) also coincides with a zone of voluminous Late Cenozoic volcanism proximal to the mountain front (Kyle, 1990) and extending beneath the Ross Sea and Ross Ice Shelf (Damaske et al., 1994; Behrendt et al., 1996; Wilson et al., 2007b). It appears that the transverse structures within the Discovery accommodation zone may have focused magmatism along a corridor transverse to the rift system, indicating a link between rift-flank structure and rift-related volcanic processes (Wilson, 1999).

The development of major volcanic edifices in this region (spanning in time from 19 Ma to recent, and including the voluminous activity associated with Mount Discovery at ca. $5 \mathrm{Ma}$ ), in turn, may have had a major influence on the patterns of glacial outflow from the TAM and the Ross Ice Shelf into the Ross Sea (Kyle, 1981; Wilson, 1999; Paulsen and Wilson, 2004).

In this context, the different content of volcanic fraction in the three petrofacies can be potentially used as an indicator of the emergence of new volcanic centers along the ice paths, which acted either as barrier with consequent changes in the flow patterns and/or provided more extensive volcanic bedrock along the path of the advancing ice sheet, with consequent modification of the debris compositions in the diamictite deposited throughout the AND-1B sedimentary record.

Based on this assumption and the extensive occurrence of lapilli tuffs, volcanogenic turbidites and a lava flow, the almost compositionally monogenic (volcanic) P1 can be interpreted as the result of primary volcanic submarine processes that origi-

Figure 8. Down-core distribution of identified petrological petrofacies (P1, P2 and P3) and provenance shifts in the AND-1B core. Lithostratigraphy after Krissek et al. (2007), with age intervals based on the initial age model of Wilson et al. (2007a). Sequence motif 1, 2 and 3 are according to Krissek et al. (2007) and McKay et al. (submitted for publication). Provenance areas include: SM Skelton-Mulock glacier area; BC Byrd-Carlyon glacier area; Loc volcanic centers in the McMurdo Sound area. Paleogeographic scenarios (A, B and C) show reconstructed pathways for ice sourced from the southern TAM outlet glaciers into the AND-1B drill site during glacial expansion in the Late Pleistocene (A), the Pliocene (B) and the Miocene (C). BG, MG, and SG schematically indicate ice flow from Byrd Glacier (northern side), Mulock Glacier, and Skelton Glacier, respectively. Flow lines in the CIROS-2 area in B are after Sandroni and Talarico (2006), those in A are based on interpretations reported in Barrett and Hambrey (1992), Ehrmann and Polozek (1999), and Sandroni and Talarico (2006). In A and B the position of Byrd Glacier flow lines is only inferred by comparison with the LGM configuration (see text for discussion). The reconstructions are based on a merged Landsat TM/Panchromatic image and do not include the corrections for isostatic/tectonic uplift. 


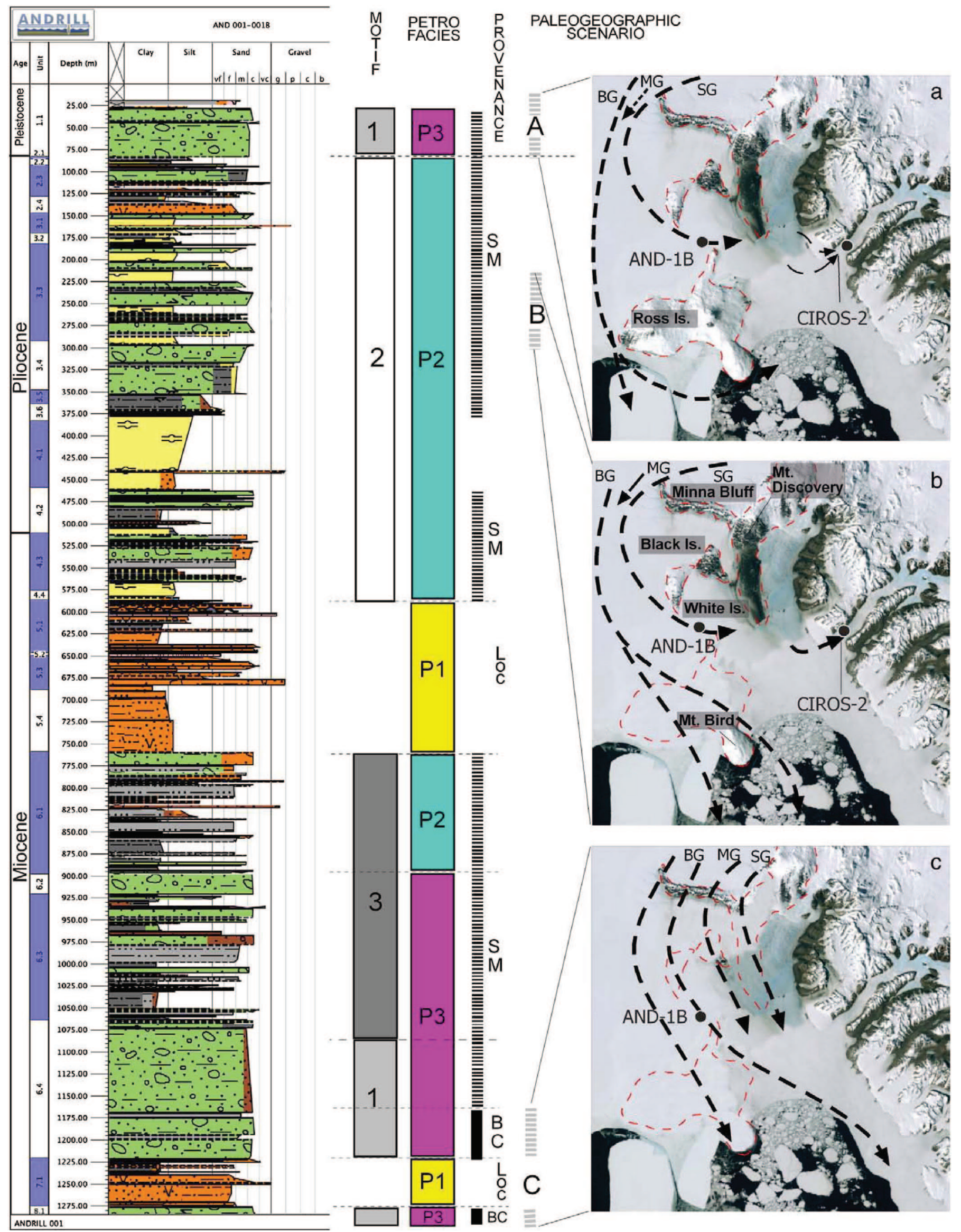


nated from a volcanic system in the vicinity of the AND-1B drill site (Di Roberto et al., 2008). The occurrence in this facies of limited amounts of intraclasts testifies to the variable sedimentary reworking of previously deposited sediments.

On the other compositional extreme, P3, with clast assemblages dominated by TAM lithologies, is the signature of remotely sourced debris eroded in the outlet EAIS glaciers of the Skelton/ Byrd glacier area.

The P2 petrofacies, compositionally similar to P1 but with a variable minor TAM component, would imply a high dilution of Skelton-Mulock sourced debris with local volcanic debris. Identified changes from P3 to P1 or P2 are indicative of sudden increases in the involvement in the erosional processes of volcanic bedrocks, and, most importantly of near-primary volcanic products. In this context both P1 and P2 facies would reflect the effects of discrete pulses of volcanic activity. Based on the available age model (Wilson et al., 2007a), which is not detailed enough to allow a deeper investigation, the AND-1B sedimentary record could have been punctuated by several volcanic episodes, some apparently documented only in the core (e.g., the lava flow at 646649 mbsf, dated at $6.38 \mathrm{Ma}$ ) and others which can be correlated to already known dated volcanic events in the exposed volcanic centers (i.e., Ross Island, Black Island, White Island).

Moreover, presently undated or unexposed volcanic units, or submarine volcanic centers underneath the McMurdo Ice Shelf (as suggested by magnetic anomalies; Wilson et al., 2007b) could also have contributed volcanic clasts to the AND-1B drill site. From this point of view, the advance of a grounded ice sheet with a basal debris load of Skelton/Byrd glacier derived basement clasts would be expected to incorporate a significant, but variable, amount of proximal volcanic debris depending on the changes in time and space of volcanic bedrock present in the drainage system.

\subsection{Short-term variability}

The long-term provenance shifts are overprinted by a number of high-frequency compositional fluctuations that appear to be coincident with changes in sedimentary processes over the glacial/ interglacial cycle. Irrespective of the type of hosting sequence motif, most glacial minima intervals are systematically enriched in volcanic detritus, with lower numbers of clasts and less varied compositions with respect to associated diamictites. In the glacial minima sediments the volcanic component is typically represented by granules with textural/mineralogical features typical of primary products, only slightly reworked by post depositional sedimentary processes (i.e., glassy lapilli, very angular to subrounded ash shards). In these intervals common intraclasts, small pebbles of felsic/intermediate lavas and a variable content of lonestones of basement lithologies indicate that volcanic processes were sometimes accompanied by sea-bottom reworking processes or ice rafted debris episodes.

The data outline several interesting aspects to be further investigated with a more focused sampling and a higher resolution study of clast variability with respect to the glacial surfaces of erosion and internal patterns within each glacial/interglacial cycle.

For example, the occurrence of the distinctive low-grade metasedimentary rocks as lonestones in diatomite facies and massive mudstone facies point to a persistent involvement of the same provenance area identified for the associated diamictite units. The association of volcanic pebbles with Skelton/Mulock glacier derived lonestones (e.g., in diatomite units, LSU 3.5, 3.6) (Talarico et al., submitted for publication) would imply that major calving processes should have been active also in the area between $\mathrm{Mu}$ lock Glacier and the southern side of Mount Morning (where both volcanic and metamorphic bedrocks are present) with possible pinning of ice tongues along Minna Bluff. Calving processes in the TAM outlet glaciers may be expected to have increased in intensity, due to expansion of these glaciers during open water conditions (assuming they had in the past the present-day low-altitude catchments), as open water conditions would have provided an increased precipitation source (e.g., Kellogg et al., 1979).
Interestingly, the variability of the gravel fraction compositions do not appear to be mirrored by the bulk sediment geochemical compositions which show an opposite pattern with TAM-enriched mudstones and volcanic-rich diamictites throughout the entire AND-1B core (Monien et al., submitted for publication). In the sand fraction, modal analyses reveal that not all glacial minima contain the same provenance signal, with either volcanic glass or quartz (e.g., Seq. 3 and 4 in the Pliocene section) (Talarico et al., submitted for publication). Understanding the significance of the decoupling of gravel-size clast compositions from those of associated fine grained sediments would require additional analytical work and a focused investigation in order to compare the different data sets. These compositional differences could simply reflect the different transport and depositional processes. Granule- to pebble-sized clasts imply either fall-out (as implied by the dominant pyroclastics in the volcanic clasts) or ice rafting from either icebergs or a glacimarine setting with distal grounding line. In contrast, bottom currents, terrigenous plumes and wind transport should be considered for the clay to sand fractions, within a more dispersive system which involved TAM-enriched debris mobilized by subglacially derived melt-water in front of the retreating ice sheet or from local TAM outlet glaciers.

Comparison of clast composition in glacial minima sediments from the three sequence motifs, as defined by Krissek et al. (2007), indicates that there is no evidence of major differences in glacial minima clast assemblages with respect to the sequence motif. Although episodic volcanic activity may have influenced the volcanic compositions (e.g., increasing the abundance of the pyroclastic component), this substantial compositional similarity suggests that volume variations of subglacially derived melt-water (dependent on the changing thermal regime of the grounded ice) were not associated with significant compositional changes and an influence of paleogeographic changes on the observed clast patterns in glacial minima intervals seem to be ruled out.

\subsection{Basement clasts provenance and integration with previous ice sheet models for the Ross Embayment}

Stuiver et al. (1981) depict LGM flow lines for the major outlet glaciers of the Transantarctic Mountains that follow the front of most part of the Transantarctic Mountains, from the Queen Maud Mountains to South Victoria Land. According to this model a multitude of potential source areas for clasts within the MIS drill core would be possible from several areas mainly consisting of low-grade metasediments associated to deformed and undeformed granitoids, with medium- to high-grade metamorphic rocks sourced from more restricted areas (e.g., upper Nimrod Glacier and Shackleton Glacier).

Although the recognition that some of the investigated pebbles can show petrographical similarities with basement lithologies exposed to the south of Byrd Glacier, a provenance from these areas appears not consistent with the very low number of pebbles of metalimestones and the apparent absence of dolomite in the investigated metalimestones in light of the very extensive exposures (more than $200 \mathrm{~km}$ ) of these rock types (i.e., the Shackleton Limestone, which includes a dominant dolomite-bearing variety, Talarico et al., 2007) in the region between Byrd and Nimrod glaciers.

Interestingly provenance investigations and resulting glacial dynamic models by Licht et al. (2005) are in conflict with the Stuiver et al. (1981) model, indicating that only the flow lines of Byrd Glacier and northernmost outlet glaciers could reach the McMurdo Sound area during the LGM.

A provenance from areas south of Byrd Glacier can therefore confidently rule out on the basis of the available data. Consequently, the identification of outlet glaciers of the Skelton-Byrd glacier area as the most likely source region for the basement clasts throughout the AND-1B glacial sediments plays a key role in the reconstruction of ice flow during the phases of grounded ice in the western Ross Embayment.

The extent of grounded ice in the Ross Embayment during and after the LGM has been investigated in detail, and glaciological 
reconstructions based on geological data in the McMurdo Sound indicate that ice flowing over the AND-1B site should have been sourced from the Mulock Glacier (Kellogg et al., 1996; Denton and Hughes, 2000, 2002) or Skelton Glacier (Drewry, 1979). The contribution of EAIS outlet glaciers to the LGM ice sheet in the Western Ross Sea is further documented by a provenance study of tills in the Ross Sea (Licht et al., 2005) which also concluded that tills deposited in the Central Ross Sea were deposited at the convergence of EAIS and WAIS derived ice, indicating an approximately equal contribution of East and West Antarctic sourced ice feeding into grounded ice in the Ross Sea area.

Consistent with glaciological models and provenance data for the LGM, the provenance constraints deduced from the basement clasts in the AND-1B core provide further evidence that even in lower Pliocene to Miocene time glacial advances at the AND-1B drill site were not the result of localized ice cap growth on bathymetric highs in the Ross Sea, or advance of local glaciers in the McMurdo Sound region (e.g., Ferrar, Blue and Koettlitz glaciers). In contrast, the provenance data firmly indicate that EAIS outlet glaciers (such as Skelton and Mulock glaciers) acted as the main ice source during glacial maxima, and corroborate the conclusion that an extensive marine-based ice sheet has periodically occupied the western Ross Embayment from Miocene to Pleistocene time.

In agreement with glaciological reconstructions, ice sheet models (MacAyeal et al., 1996; Hulbe and MacAyeal, 1999; Ritz et al., 2001; Huybrechts, 2002) require ice from WAIS to force the flow lines of the southern TAM outlet glaciers into the McMurdo region during glacial periods, and to maintain an ice shelf during ensuing interglacial retreats. This model is supported by a new ice sheet-shelf model (Pollard and DeConto, 2009), that simulates Antarctic ice volume fluctuations of up to $+8 \mathrm{~m}$ equivalent sea level, in response to ocean-induced melting paced by obliquity (Naish et al., 2009). In this model, the mass balance of the predominantly marine-based ice sheet within the Ross Embayment was controlled by the same influences as the WAIS as a whole (e.g., eustasy, iceberg calving and sub-ice shelf melting), which is very different from the high-elevation land-based EAIS.

In this context, the sedimentary cycles in the AND-1B core record the expansion and contraction of the coastal margin of the EAIS (e.g., TAM outlet glaciers) in concert with oscillations in the extent of the WAIS. Conceptually, changes in glacial volume over either West or East Antarctica may have altered the flow-line paths of TAM outlet glaciers that feed into the Ross Embayment. A thicker WAIS may result in diverting more ice derived from the Byrd Glacier region, rather than the Mulock or Skelton glaciers, into the vicinity of AND-1B (compare A and C scenarios in Figure 8).

Following this model the shift from Carlyon-Byrd to SkeltonMulock sourced debris identified in the Middle to Late Miocene part of the core could be interpreted as the provenance signature of a decreased WAIS contribution, which resulted in an increased flux of ice derived from the Mulock-Skelton region.

As discussed above, changes in paleogeography represent an additional complexity that should be carefully assessed for their influences on the provenance signal and past glacial flow-line pathways. In the absence of Ross Island and of White Island (Cooper et al., 2007), a smaller Minna Bluff that was overridden by ice during glacial maxima (e.g., at ca. $10 \mathrm{Ma}$, as documented by a significant glacial unconformity, Wright and Kyle, 1990b) and a smaller Black Island (Armstrong, 1978), ice derived from the Byrd Glacier is more likely to have flowed through the AND-1B drill site during the Late Miocene (C scenario in Figure 8).

Unfortunately, the age of sedimentary strata around the identified shift can be only grossly constrained within a large time window between 6.38 and 13.4 Ma. As a consequence of this, a detailed assessment of the influences of the emergence of major volcanic centers on ice flow patterns in Miocene time can be considered very likely but non exhaustively proven until new data, namely from an improved chronology of the volcanic evolution in key areas such as Minna Bluff and of the AND-1B record below $600 \mathrm{mbsf}$, become available.

Deposition of the Pliocene and Pleistocene sequences (age $<6 \mathrm{Ma}$ ) occurred in the presence of Minna Bluff (11-7.26 Ma), the voluminous volcanic activity associated to Mount Discovery (beginning at 5.44 Ma), and, from 4.6 Ma to recent time, during the progressive building of Ross Island.

The presence of Minna Bluff and the development of a larger Ross Island very likely resulted in preventing the SVL outlet glaciers from flowing far from the TAM front and in diverting most of the Byrd Glacier flow lines to the east of Ross Island (A scenario in Figure 8).

The reconstructed ice directions and ice dynamic model are comparable to the configurations proposed by Drewry (1979), Kellogg et al. (1996), and Denton and Hughes $(2000,2002))$ for the grounded ice expansion within the McMurdo Sound during the LGM, and they are also consistent with ice flow patterns previously reconstructed for Pliocene (Sandroni and Talarico, 2006) and Pleistocene (Barrett and Hambrey, 1992; Ehrmann and Polozek, 1999; Sandroni and Talarico, 2006) glacial settings in the region.

Acknowledgments - The ANDRILL project is a multinational collaboration between the Antarctic programs of Germany, Italy, New Zealand and the United States. We would like to acknowledge T. Paulsen and J. Smellie for their helpful comments and suggestions, and the whole ANDRILL MIS Science Team for their contribution to the successful drilling project.

\section{References}

Allibone et al., 1993a - A. H. Allibone, S. C. Cox, and R. W. Smillie, Granitoids of the Dry Valleys area, southern Victoria Land: Geochemistry and evolution along the early Paleozoic Antarctic craton margin, New Zealand Journal of Geology and Geophysics 36 (1993), pp. 281-297.

Allibone et al., 1993b - A. H. Allibone, S. C. Cox, I. J. Graham, R. W. Smillie, R. D. Johnstone, S. G. Ellery, and K. Palmer, Granitoids of the Dry Valleys area, southern Victoria Land, Antarctica: Plutons, field relationships, and isotopic dating, New Zealand Journal of Geology and Geophysics 36 (1993), pp. 281-297.

Armstrong, 1978 - R. L. Armstrong, K-Ar dating; Late Cenozoic McMurdo Volcanic Group and Dry Valley glacial history, Victoria Land, Antarctica, New Zealand Journal of Geology and Geophysics 21 (1978), pp. 685-698.

Barrett, 1999 - P. Barrett, Antarctic climate history over the last 100 million years, Terra Antartica Reports 3 (1999), pp. 53-72.

Barrett and Hambrey, 1992 - P. J. Barrett and M. J. Hambrey, Plio-Pleistocene sedimentation in the Ferrar Fiord, Antarctica, Sedimentology 39 (1992), pp. 109-123.

Bart and Anderson, 2000 - P. J. Bart and J. B. Anderson, Relative temporal stability of the Antarctic ice sheets during the late Neogene based on the minimum frequency of outer shelf grounding events, Earth and Planetary Science Letters 182 (2000), pp. 259-272.

Behrendt et al., 1996 • J. C. Behrendt, R. Saltus, D. Damaske, A. McCafferty, C. Finn, D. D. Blankenship, and R. E. Bell, Patterns of late Cenozoic volcanic and tectonic activity in the West Antarctic Rift System revealed by aeromagnetic surveys, Tectonics 15 (1996), pp. 660-676.

Borg et al., 1989 - S. G. Borg, D. J. DePaolo, E. D. Wendlandt, and T. G. Drake, Studies of granites and metamorphic rocks, Byrd Glacier area, Antarctic Journal of the United States 24 (1989), pp. 19-21.

Bucher and Frey, 1994 - K. Bucher and M. Frey, Petrogenesis of Metamorphic Rocks, Springer (1994).

Cape Roberts Science Team, 1998a - Cape Roberts Science Team, Quaternary strata in CRP-1, Cape Roberts Project, Antarctica, Terra Antartica 5 (1998), pp. 31-62.

Cape Roberts Science Team, 1998b - Cape Roberts Science Team, Miocene strata in CRP-1, Cape Roberts Project, Antarctica, Terra Antartica 5 (1998), pp. 63-124.

Cape Roberts Science Team, 1999 • Cape Roberts Science Team, Studies from the Cape Roberts Project, Ross Sea, Antarctica. Initial Report on CRP-2/2A, Terra Antartica 6 (1/2) (1999), pp. 1-173.

Carosi et al., 2007 • R. Carosi, F. Giacomini, F. Talarico, and E. Stump, Geology of the Byrd Glacier discontinuity (Ross Orogen): New survey data from the Britannia Range, Antarctica. In: A. K. Cooper and C. R. Raymond et al., Editors, Antarctica: A Keystone in a Changing World Online Proceedings of the 10th ISAES (2007), doi: 10.3133/of2007-1047. srp030 ; USGS Open-File Report 2007-1047, Short Research Paper 030, $6 \mathrm{pp}$.

Cottle and Cooper, 2006a - J. M. Cottle and A. F. Cooper, Geology, geochemistry and geochronology of an A-type granite in the Mulock Glacier area, southern Victoria Land, Antarctica, New Zealand Journal of Geology and Geophysics 49 (2006), pp. 191-202. 
Cottle and Cooper, 2006b - J. M. Cottle and A. F. Cooper, The Fontaine Pluton: an early Ross Orogeny calc-alkaline gabbro from southern Victoria Land, Antarctica, New Zealand Journal of Geology and Geophysics 49 (2006), pp. 177-189.

Cook, 1997 - Y. Cook, The Skelton Group and the Ross Orogeny, Ph.D. Thesis, University of Otago, Dunedin, 1997.

Cook, 2007 - Y. A. Cook, Precambrian rift-related magmatism and sedimentation, south Victoria Land, Antarctica, Antarctic Science 19 (2007), pp. $471-484$.

Cook and Craw, 2001 - Y. A. Cook and D. Craw, Amalgamation of disparate crustal fragments in the Walcott Bay - Foster Glacier area, South Victoria Land, Antarctica, New Zealand Journal of Geology and Geophysics 44 (2001), pp. 403-416.

Cook and Craw, 2002 - Y. A. Cook and D. Craw, Neoproterozoic structural slices in the Ross orogen, Skelton Glacier area, south Victoria Land, New Zealand Journal of Geology and Geophysics 45 (2002), pp. 133-143.

Cooper and Davey, 1985 - A. K. Cooper and F. J. Davey, Episodic rifting of the Phanerozoic rocks of the Victoria Land basin, western Ross Sea, Antarctica, Science 229 (1985), pp. 1085-1087.

Cooper et al., 1991 - A. K. Cooper, P. J. Barrett, K. Hinz, V. Traube, G. Leitchenkov, and H. M. J. Stagg, Cenozoic prograding sequences of the Antarctic continental margin: a record of glacio-eustatic and tectonic events, Marine Geology 102 (1991), pp. 175-213.

Cooper et al., 1997 - A. F. Cooper, B. A. Worley, R. A. Armstrong, and R. C. Price, Synorogenic alkaline and carbonatitic magmatism in the Transantarctic Mountains of South Victoria Land, Antarctica. In: C. A. Ricci, Editor, The Antarctic Region: Geological Evolution and Processes, Siena, Terra Antarctica Publication (1997), pp. 245-252.

Cooper et al., 2007 • A. F. Cooper, L. J. Adam, R. F. Coulter, G. N. Eby, and W. C. McIntosh, Geology, geochronology and geochemistry of a basinite volcano, White Island, Ross Sea, Antarctica, Journal of Volcanology and Geothermal Research 165 (2007), pp. 189-216.

Craddock, 1970 - C. Craddock, Tectonic map of Gondwana, in geologic maps of Antarctica. In: V. C. Bushnell and C. Craddock, Editors, Antarctic Map Folio Series, Folio 12, plate XXIII, Amer. Geogr. Soc., New York (1970).

Crowley, 1996 - T. J. Crowley, Pliocene climates: The nature of the problem, Mar. Micropaleontol. 27 (1996), pp. 3-12.

Damaske et al., 1994 - D. Damaske, J. Behrendt, A. McCafferty, R. Saltus, and U. Meyer, Transfer faults in the western Ross Sea: new evidence from the McMurdo Sounds/Ross Ice Shelf aeromagnetic survey (GANOVEX VI), Antarctic Science 6 (1994), pp. 359-364.

Denton and Hughes, 2000 - G. H. Denton and T. J. Hughes, Reconstruction of the Ross ice drainage system, Antarctica, at the last glacial maximum, Geografiska Annaler 82A (2000), pp. 143-166.

Denton and Marchant, 2000 - G. H. Denton and D. R. Marchant, The geologic basis for a reconstruction of a grounded ice sheet in McMurdo Sound, Antarctica, at the last glacial maximum, Geografiska Annaler 82A (2000), pp. 167-211.

Denton and Hughes, 2002 - G. H. Denton and T. J. Hughes, Reconstructing the Antarctic ice sheet at the last glacial maximum, Quaternary Science Reviews 21 (2002), pp. 203-231.

Di Roberto et al., 2008 - A. Di Roberto, M. Pompilio, and T. Wilch, Miocenic subaqueous volcaniclastic deposits in ANDRILL-MIS core. Eos Trans. AGU 89 (2008), Fall Meet. Suppl., Abstract, C21B-0535.

Drewry, 1979 - D. J. Drewry, Late Wisconsin reconstruction for the Ross Sea region, Antarctica, J. Glaciol. 24 (1979), pp. 231-244.

Drewry, 1983 - D. J. Drewry, Antarctica: Glaciological and Geophysical Folio, Scott Polar Research Institute, Cambridge, United Kingdom, University of Cambridge (1983) $9 \mathrm{pp}$

Ehrmann and Polozek, 1999 - W. Ehrmann and K. Polozek, The heavy mineral record in the Pliocene to Quaternary sediments of the CIROS-2 drill core, McMurdo Sound, Antarctica, Sediment. Geol. 128 (1999), pp. 223-244.

Fahnestock et al., 2000 - M. A. Fahnestock, T. A. Scambos, R. A. Bindschadler, and G. Kvaran, A millennium of variable ice flow recorded by the Ross Ice Shelf, Antarctica, Journal of Glaciology, 46 (2000), pp. 652-664.

Findlay et al., 1984 - R. H. Findlay, D. N. B. Skinner, and D. Craw, Lithostratigraphy and structure of the Koettlitz Group, McMurdo Sound, Antarctica, New Zealand Journal of Geology and Geophysics 27 (1984), pp. 513-536

Fitzgerald, 2002 - P. G. Fitzgerald, Tectonics and landscape evolution of the Antarctic plate since the breakup of Gondwana, with an emphasis on the West Antarctic Rift System and the Transantarctic Mountains. In: J. Gamble and D. A. Skinner, Editors, Proceedings of the 8th International Symposium on Antarctic Earth Science, N. Z. Bull. vol. 35, Royal Soc. (2002), pp. 435-469.

Gerya et al., 1997 • T. V. Gerya, L. L. Perchuk, C. Triboulet, C. Audren, and A. I. Sezko, Petrology of the Tumanshet zonal metamorphic complex, Eastern Sayan, Petrology 47 (1997), pp. 165-185.
Grindley, 1963 - G. W. Grindley, The geology of the Queen Alexandra Range, Beardmore Glacier, Ross Dependency, Antarctica; with notes on the correlation of Gondwana sequences, New Zealand Journal of Geology and Geophysics 6 (1963), pp. 307-347.

Grindley and Warren, 1964 • G. W. Grindley and G. Warren, Stratigraphic nomenclature and correlation in the western part of the Ross Sea. In: R. J. Adie, Editor, Antarctic Geology, North Holland Publishing Co., Amsterdam (1964), pp. 314-333.

Gunn and Warren, 1962 • B. M. Gunn and G. Warren, Geology of Victoria Land between the Mawson and Mulock glaciers, Antarctica, New Zealand Geological Survey 71 (1962).

Harrington, 1965 - H. J. Harrington, Geology and morphology of Antarctica. Biogeography and ecology in Antarctica, Monogr. Biol. 15 (1965), pp. $1-71$.

Henrys et al., 2007 • S. A. Henrys, T. J. Wilson, J. Whittaker, C. R. Fielding, J. Hall, and T. R. Naish, Tectonic history of Mid-Miocene to Present southern Victoria Land basin, inferred from seismic stratigraphy, in McMurdo Sound, Antarctica. In: A. K. Cooper and C. R. Raymond, Editors, Antarctica: A Keystone in a Changing World-Online Proceedings for the Tenth International Symposium on Antarctic Earth Sciences (2007) USGS Open-File Report 2007-1047, Short Research Paper 049.

Hughes, 1973 - T. J. Hughes, Is the West Antarctic Ice Sheet disintegrating? J. Geophys. Res. 78 (1973), pp. 7884-7910.

Hughes, 1977 - T. J. Hughes, West Antarctic ice streams, Reviews of Geophysics and Space Physics 15 (1977), pp. 1-46.

Hulbe and MacAyeal, 1999 • C. Hulbe and D. MacAyeal, A new numerical model of coupled inland ice sheet, ice stream, and ice shelf flow and its application to the West Antarctic Ice Sheet, Journal of Geophysical Research 104 (1999), pp. 349-366.

Huybrechts, 2002 - P. Huybrechts, Sea-level changes at the LGM from icedynamic reconstructions of the Greenland and Antarctic ice sheets during the glacial cycles, Quaternary Science Reviews 21 (2002), pp. 203-231.

Jones, 1997 S. Jones, Late Quaternary faulting and neotectonics, south Victoria Land, Antarctica, Journal of the Geological Society of London 154 (1997), pp. 645-652.

Kellogg et al., 1979 • T. B. Kellogg, R. S. Truesdale, and L. E. Osterman, Late quaternary extent of the West Antarctic ice sheet: New evidence from Ross cores, Geology 7 (1979), pp. 249-253.

Kellogg et al., 1996 - T. B. Kellogg, T. Hughes, and D. E. Kellogg, Late Pleistocene interactions of East and West Antarctic ice-flow regimes: Evidence from the McMurdo Ice Shelf, Journal of Glaciology 42 (1996), pp. $486-500$.

Kyle, 1981 - P. R. Kyle, Mineralogy and geochemistry of a basanite to phonolite sequence at Hut Point Peninsula, Antarctica, based on core from Dry Valley Drilling Project Drillholes 1, 2 and 3, Journal of Petrology 22 (1981), pp. 451-500.

Kyle, $1990 \bullet$ P. R. Kyle, A. McMurdo volcanic group, western Ross Embayment. Introduction. In: W. E. Le Masurier and J. W. Thomson, Editors, Volcanoes of the Antarctic Plate and Southern Oceans, AGU Antarctic Research Series vol. 48 (1990), pp. 19-25.

Kyle and Muncy, 1983 - P. R. Kyle and H. L. Muncy, The geology of the mid-Miocene McMurdo Volcanic Group at Mount Morning, McMurdo Sound, Antarctica. In: R. L. Oliver, P. R. James, and J. B. Jago, Editors, Antarctic Earth Science, Fourth International Symposium, Cambridge University Press, Cambridge (1983).

Kyle et al., 1981 • P. R. Kyle, D. H. Elliot, and J. F. Sutter, Jurassic Ferrar Supergroup tholeiites from the Transantarctic Mountains, Antarctica, and their relationship to the initial fragmentation of Gondwana. In: M. M. Cresswell and P. Vella, Editors, Gondwana Five, Fifth International Gondwana Symposium (1981), pp. 283-287.

Kretz, 1983 - R. Kretz, Symbols for rock forming minerals, Am. Mineral. 68 (1983), pp. 277-279.

Krissek et al., 2007 • L. A. Krissek, G. H. Browne, L. Carter, E. A. Cowan, G. B. Dunbar, R. M. McKay, T. Naish, R. Powell, J. Reed, T. I. Wilch, and The ANDRILL MIS Science Team, Sedimentology and stratigraphy of the AND-1B core, ANDRILL McMurdo Ice Shelf Project, Antarctica, Terra Antartica 14 (2007), pp. 185-222.

Leake et al., 1997 • B. E. Leake, A. R. Woolley, C. E. S. Arps, W. D. Birch, M. C. Gilbert, J. D. Grice, F. C. Hawthorne, F. C. Kato, H. J. Kisch, V. G. Krichovichev, K. Linthout, J. Lair, J. A. Mandarino, W. V. Maresch, E. H. Nickel, N. M. S. Rock, J. C. Schumacher, D. C. Smith, N. C. M. N. Stephenson, L. Ungaretti, E. J. W. Whittaker, and G. Youzhi, Nomenclature of amphiboles: Report of the subcommittee on amphiboles of the International Mineralogical Association, commission on new minerals and mineral names, American Mineralogist 82 (1997), pp. 1019-1037.

Licht et al., 2005 • K. J. Licht, J. R. Lederer, and J. R. Swope, Provenance of LGM glacial till (sand fraction) across Ross Embayment, Antarctica, Quaternary Science Reviews 24 (2005), pp. 1499-1520.

Lisiecki and Raymo, 2005 • L. E. Lisiecki and M. E. Raymo, A PliocenePleistocene stack of 57 globally distributed benthic $\delta^{18} \mathrm{O}$ records, Paleoceanography 20 (2005), pp. 1-17. 
Loomis, 1966 - A. A. Loomis, Contact metamorphic reactions and process in the Mt. Tallac roof remnant, Sierra Nevada, California, Journal of Petrology 7 (1966), pp. 221-245.

MacAyeal et al., 1996 - D. R. MacAyeal, V. Rommelaere, P. Huybrechts, C. L. Hulbe, J. Determann, and C. Ritz, An ice shelf model test based on the Ross Ice Shelf, Antarctica, Annals of Glaciology 23 (1996), pp. 46-51.

McKay et al., 2009 • R. McKay, G. Browne, L. Carter, E. Cowan, L. Krissek, T. Naish, R. Powell, J. Reed, F. Talarico, and T. Wilch, The stratigraphic signature of the Late Cenozoic Antarctic ice sheets in the Ross Embayment, Bulletin of the Geological Society of America 121 (2009), pp. 1537-1561.

Monien et al., submitted for publication - D. Monien, G. Kuhn, H. von Eynatten, and F. M. Talarico, Provenance analysis of Ross Embayment basin deposits as evidence for West Antarctic Ice Sheet growth, Global and Planetary Change, submitted for publication.

Mosola and Anderson, 2006 - A. B. Mosola and J. B. Anderson, Expansion and rapid retreat of the West Antarctic Ice Sheet in Eastern Ross Sea: Possible consequence of over extended ice streams?, Quaternary Science Reviews 25 (2006), pp. 2177-2196.

Miyashiro, 1961 - A. Miyashiro, Evolution of metamorphic belts, J. Petrology 2 (1961), pp. 277-311.

Naish et al., 2007 - T. R. Naish, R. D. Powell, R. H. Levy, and The ANDRILL MIS Science Team, Initial science results from AND-1B, ANDRILL McMurdo Ice Shelf Project, Antarctica, Terra Antartica 14 (2007), pp. 111-328.

Naish et al., 2009 • T. Naish, R. Powell, R. Levy, G. Wilson, R. Scherer, F. Talarico, L. Krissek, F. Niessen, M. Pompilio, T. Wilson, L. Carter, R. DeConto, P. Huybers, R. McKay, D. Pollard, J. Ross, D. Winter, P. Barrett, G. Browne, R. Cody, E. Cowan, J. Crampton, G. Dunbar, N. Dunbar, F. Florindo, C. Gebhardt, I. Graham, M. Hannah, D. Hansaraj, D. Harwood, D. Helling, S. Henrys, L. Hinnov, G. Kuhn, P. Kyle, A. Läufer, P. Maffioli, D. Magens, K. Mandernack, W. McIntosh, C. Millan, R. Morin, C. Ohneiser, T. Paulsen, D. Persico, I. Raine, J. Reed, C. Riesselman, L. Sagnotti, D. Schmitt, C. Sjunneskog, P. Strong, M. Taviani, S. Vogel, T. Wilch, and T. Williams, Obliquity-paced Pliocene West Antarctic ice sheet oscillations, Nature 458 (2009), pp. 322-328.

Oppenheimer, 1998 - M. Oppenheimer, Global warming and the stability of the West Antarctic Ice Sheet, Nature 393 (1998), pp. 325-332.

Passchier and Trouw, 1996 - C. W. Passchier and R. A. J. Trouw, Microtectonics, Springer Verlag (1996).

Paulsen and Wilson, 2004 - T. Paulsen and T. Wilson, Subglacial bedrock structure in the Transantarctic Mountains and its influence on ice sheet flow: Insights from RADARSAT SAR imagery, Global and Planetary Change 42 (2004), pp. 227-240.

Pollard and DeConto, 2009 - M. Pollard and D. DeConto, Modelling West Antarctic ice sheet growth and collapse through the last 5 million years, Nature 458 (2009), pp. 329-332.

Pompilio et al., 2007 - M. Pompilio, N. Dunbar, A. C. Gebhardt, D. Helling, G. Kuhn, P. Kyle, R. McKay, F. Talarico, S. Tulaczyk, S. Vogel, T. Wilch, and The ANDRILL-MIS Science Team, Petrology and geochemistry of the AND-1B Core, ANDRILL McMurdo Ice Shelf Project, Antarctica, Terra Antartica 14 (2007), pp. 255-288.

Raymo et al., 1996 - M. E. Raymo, B. Grant, M. Horowitz, and G. H. Rau, Mid-Pliocene warmth: Stronger greenhouse and stronger conveyor, Marine Micropaleontology 27 (1996), pp. 313-326.

Ritz et al., 2001 - C. Ritz, V. Rommelaere, and C. Dumas, Modelling the evolution of Antarctic ice sheet over the last 420,000 years: Implications for altitude changes in the Vostok region, Journal of Geophysical Research-Atmospheres 106 (2001), pp. 31943-31964.

Rowell et al., 1993 - A. J. Rowell, M. N. Rees, E. M. Duebendorfer, E. T. Wallin, S. W. R. Van, and E. I. Smith, An active Neoproterozoic margin; Evidence from the Skelton Glacier area, Transantarctic Mountains, Journal of the Geological Society of London 150 (1993), pp. 677-682.

Sandroni and Talarico, 2006 - S. Sandroni and F. M. Talarico, Analysis of clast lithologies from CIROS-2 core, New Harbour, Antarctica - Implications for ice flow directions during Plio-Pleistocene, Palaeoleography, Palaeoclimatology, Palaeoecology 231 (2006), pp. 215-232.

Skinner, 1982 - D. N. B. Skinner, Stratigraphy and structure of low-grade meta-sedimentary rocks of the Skelton Group, southern Victoria Land - Does teal greywacke really exist?. In: C. Craddock, Editor, Antarctic geoscience, University of Wisconsin Press, Madison (1982), pp. 555-563.

Smellie, 2000 - J. L. Smellie, Erosional history of the Transantarctic Mountains deduced from sand grain detrital modes in CRP-2/2A, Victoria Land Basin, Antarctica, Terra Antartica 7 (2000), pp. 545-552.
Smellie, 2001 - J. L. Smellie, History of Oligocene erosion, uplift and unroofing of the Transantarctic Mountains deduced from sandstone detrital modes in CRP-3 drillcore, Victoria Land Basin, Antarctica, Terra Antartica 8 (2001), pp. 481-489.

Stuiver et al., 1981 • M. Stuiver, G. H. Denton, T. J. Hughes, and J. L. Fastook, History of the marine ice sheets in West Antarctica during the last glaciation: a working hypothesis. In: G. H. Denton and T. J. Hughes, Editors, The Last Great Ice Sheets, Wiley-Interscience, New York (1981), pp. 319-439.

Stump et al., 2004 - E. Stump, B. Gootee, F. Talarico, W. R. Van Schmus, P. K. Brand, K. A. Foland, and C. M. Fanning, Correlation of Byrd and Selborne groups, with implications for the Byrd Glacier discontinuity, central Transantarctic Mountains, New Zealand Journal of Geology and Geophysics 47 (2004), pp. 157-171.

Talarico et al., submitted for publication - F. M. Talarico, R. M. McKay, R. D. Powell, S. Sandroni, and T. Naish, The Late Cenozoic oscillations of the Antarctic Ice sheets revealed by provenance of basement clasts and grain detrital modes in ANDRILL core AND-1B, Global and Planetary Change, submitted for publication.

Talarico et al., 2000 • F. M. Talarico, S. Sandroni, C. Fielding, and C. Atkins, Variability, petrography and provenance of basement clasts from CRP-2/2A drillcore (Victoria Land Basin, Antarctica), Terra Antartica 7 (2000), pp. 529-544.

Talarico et al., 2005 - F. M. Talarico, R. Findlay, and N. Rastelli, Metamorphic evolution of the Koettlitz Group in the Koettlitz-Ferrar Glaciers region (southern Victoria Land, Antarctica), Terra Antartica 12 (2005), pp. 3-23.

Talarico and Sandroni, 2007 - F. M. Talarico, S. Sandroni , and MIS Science Team, Clast provenance and variability in MIS (AND-1B) core and their implications for the paleoclimatic evolution recorded in the Windless Bight - southern McMurdo Sound area (Antarctica). In: A. K. Cooper et al., Editors, Program Book for the 10th ISAES, Open-File Report 2007 vol. 104, IUGS (2007), p. 14.

Williams et al., 1971 • P. F. Williams, B. E. Hobbs, R. H. Vernon, and D. E. Anderson, The structural and metamorphic geology of basement rocks in the McMurdo Sound area, Antarctica, Journal of the Geological Society of Australia 18 (1971), pp. 127-142.

Wilson, 1999 • T. J. Wilson, Cenozoic structural segmentation of the Transantarctic Mountains rift flank in southern Victoria Land, Global and Planetary Change 23 (1999), pp. 105-127.

Wilson et al., 2007a • G. Wilson, R. Levy, G. Browne, N. Dunbar, F. Florindo, S. Henrys, I. Graham, W. McIntosh, R. McKay, T. Naish, Ohneiser, R. Powell, J. Ross, L. Sagnotti, R. Scherer, C. Sjunneskog, C. Strong, M. Taviani, D. Winter, and The ANDRILL MIS Science Team, Preliminary chronostratigraphy of the AND-1B core, ANDRILL McMurdo Ice Shelf Project, Antarctic, Terra Antartica 14 (2007), pp. 297-316.

Wilson et al., 2007b • G. Wilson, D. Damaske, H.-D. Möller, K. Tinto, and T. Jordan, The geological evolution of southern McMurdo Sound New evidence from a high-resolution aeromagnetic survey, Geophysical Journal International 170 (2007), pp. 93-100.

Wright and Kyle, 1990a - A. C. Wright and P. R. Kyle, Mount Bird. In: W. E. LeMasurier and J. W. Thomson, Editors, Volcanoes of the Antarctica Plate and Southern Oceans, Antarctic Research Series vol. 48, American Geophysical Union (1990), pp. 97-98.

Wright and Kyle, 1990b - A. C. Wright and P. R. Kyle, Minna Bluff. In: W. E. LeMasurier and J. W. Thompson, Editors, Volcanoes of the Antarctic Plate and Southern Oceans, Antarctic Research Series vol. 48, American Geophysical Union (1990), pp. 117-119.

Wright-Grassham, 1987 • A. Wright-Grassham, Volcanic geology, mineralogy and petrology of the discovery volcanic subprovince, southern Victoria Land, Antarctica, Ph.D. Thesis, New Mexico Institute of Mining and Technology, 1987.

Zachos et al., 2001 • J. C. Zachos, M. Pagani, L. C. Sloan, E. Thomas, and K. Billups, Trends, rhythms, and aberrations in global climate $65 \mathrm{Ma}$ to present, Science 292 (2001), pp. 686-693.

Zenk and Schulz, 2004 - M. Zenk and B. Schulz, Zoned Ca-amphiboles and related P-T evolution in metabasites from the classical Barrovian metamorphic zones in Scotland, Mineralogical Magazine 68 (2004), pp. 769-786. 